\title{
Evaluation of the relative contribution of meteorological and oceanic forces to the drift of ice islands offshore Newfoundland
}

\section{Paper}

Cite this article: Zeinali Torbati R, Turnbull ID, Taylor RS, Mueller D (2020). Evaluation of the relative contribution of meteorological and oceanic forces to the drift of ice islands offshore Newfoundland. Journal of Glaciology 66(256), 203-218. https://doi.org/10.1017/ jog.2019.96

Received: 23 August 2018

Revised: 23 November 2019

Accepted: 25 November 2019

First published online: 10 January 2020

\section{Key words:}

Atmospheric and oceanic forces; basal ablation; ice island deterioration; ice island drift; sea-ice force; surface ablation

\section{Author for correspondence:}

Reza Zeinali Torbati, E-mail: rzt313@mun.ca
Reza Zeinali Torbati ${ }^{1}$ (D), Ian D. Turnbull ${ }^{2}$, Rocky S. Taylor ${ }^{1}$ and Derek Mueller ${ }^{3}$

${ }^{1}$ Department of Engineering and Applied Science, Memorial University of Newfoundland, S.J. Carew Building, 240 Prince Philip Drive, St. John's, NL A1B 3X5, Canada; ${ }^{2}$ Ice Engineering, C-CORE, Captain Robert A. Bartlett Building, 1 Morrissey Road, St. John's, NL A1B 3X5, Canada and ${ }^{3}$ Department of Geography and Environmental Studies, Carleton University, B349 Loeb Building, 1125 Colonel By Drive, Ottawa, ON K1S 5B6, Canada

\section{Abstract}

On 29 April 2015, four beacons were deployed onto an ice island in the Strait of Belle Isle to record positional data. The ice island later broke up into many fragments, four of which were tracked by the beacons. The relative influences of wind drag, current drag, Coriolis force, sea surface height gradient and sea-ice force on the drift of the tracked ice island fragments were analyzed. Using atmospheric and oceanic model outputs, the sea-ice force was calculated as the residual of the fragments' net forces and the sum of all other forces. This was compared against the force obtained through ice concentration-dependent relationships when sea ice was present. The sea-ice forces calculated from the residual approach and concentration-dependent relationships were significant only when sea ice was present at medium-high concentrations in the vicinity of the ice island fragments. The forces from ocean currents and sea surface tilt contributed the most to the drift of the ice island fragments. Wind, however, played a minimal role in the total force governing the drift of the four ice island fragments, and Coriolis force was significant when the fragments were drifting at higher speeds.

\section{Introduction}

Due to the increasing demand in global energy, oil and gas exploration has advanced into iceprone environments where the occurrence of ice islands (large tabular icebergs) is possible. The occasional presence of ice islands in the eastern Canadian Arctic may pose serious risks to offshore structures and vessels operating in these regions (Mueller and others, 2013). These risks can be reduced by executing appropriate ice avoidance strategies, which require an accurate drift-forecasting model. The effectiveness of an ice avoidance strategy rests upon the drift velocity of the ice features, which are governed by the meteorological and oceanic forces on an ice island.

In order to characterize the ice environment and better understand the drift dynamics of icebergs and ice islands in ice-infested waters, it is important to study the influence of atmospheric and oceanic forces on their overall drift, including drag from wind and ocean currents, the Coriolis force, the gravitational pull caused by the sea surface height gradient and the force imposed by the surrounding sea ice. While there have been several studies on drift forecast modeling of icebergs and ice islands in open water (e.g. Mountain, 1980; Crepon and others, 1988; Kubat and others, 2005), if sea ice is present, these models would need to be extended to account for the effect of sea ice on the drift of such ice features, as the drift characteristics (e.g. speed and trajectory) are readily influenced by medium-high concentrations of sea ice in the environment (Lichey and Hellmer, 2001). Since a reliable drift model in a sea-ice-prone environment can only be developed if appropriate data are available, positional data for the drift of four ice island fragments within the sea-ice environment offshore Newfoundland were collected for model development.

This study evaluates the relative contributions of meteorological and oceanic forces caused by wind, current, Coriolis force, sea surface height and sea ice to the drift of four ice island fragments tracked at the northeast entrance to the Strait of Belle Isle offshore Newfoundland (Fig. 1). To improve the reliability of estimates for the atmospheric and oceanic forces, the variation in the mass of the ice island fragments was estimated through the dimensional reduction in the horizontal and vertical extents, and then incorporated into the presented force analysis. The forces due to wind, current, Coriolis effect and sea surface tilt were calculated using reanalysis data and observed fragment drift velocity (from the tracking beacon data). The sea-ice force, however, was calculated using the residual approach that was used in Turnbull and others (2017), where the internal stress gradient force from surrounding ice on the drift of sea-ice floes was estimated. In this study, however, we used the residual approach (Turnbull and others, 2017) to estimate the influence of sea-ice force on the total force that governs the drift of ice islands, where the force from sea ice was calculated as the difference between the net force and the sum of other meteorological and oceanic forces on each fragment. The net force was calculated using the mass (estimated as per Section 2.6.) and the observed acceleration of the fragments; the latter was estimated from the positional 


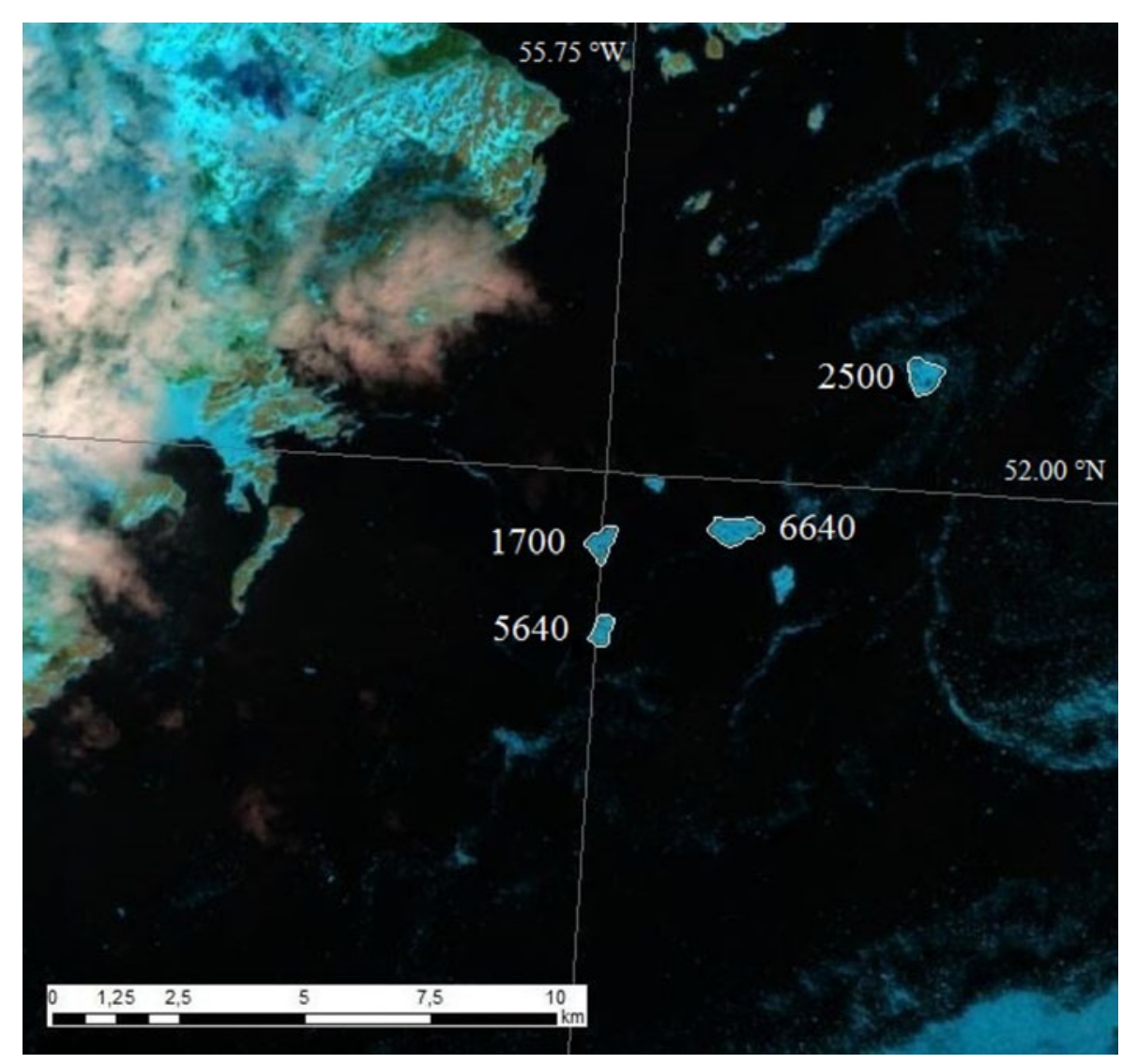

Fig. 1. Landsat 8 image taken on 7 May 2015 over the NE Strait of Belle Isle showing the ice island breaking up into several smaller fragments (image is courtesy of Sigurd Teigen, Equinor ASA). The numbers next to the fragments indicate the last four digits of the tracking beacon International Mobile Equipment Identity (IMEI) numbers.

data transmitted by the tracking beacons. This residual-estimated force was then compared and validated against sea-ice force estimated from Lichey and Hellmer's iceberg drift model (2001) during the presence of sea ice. Finally, a sensitivity analysis was conducted to present the results over a range of air and water drag coefficients.

\subsection{Previous studies on drift and deterioration of icebergs and ice islands}

Operational drift and deterioration models for icebergs have been developed by several agencies such as the Canadian Ice Service (CIS) and International Ice Patrol (White and others, 1980; Kubat and others, 2005, 2007; Murphy and Carrieres, 2010). The accuracy of these models is limited by the complexity in the iceberg geometry due to the occasional calving and rolling events (Kubat and others, 2007), as well as by the uncertainty in atmospheric and oceanic model outputs. Adding to this complexity is the fact that the meteorological and oceanic conditions constantly change over time. Therefore, it is necessary to calibrate these models and combine them with field observations to develop reliable drift and deterioration models.

Several studies have been conducted on the drift of icebergs, both in open water and in the presence of sea ice. One of the initial models was presented by Smith and Banke (1983), in which the iceberg drift was simulated under the influence of winds, ocean currents and Coriolis deflection. An iceberg drift model was introduced by Lichey and Hellmer (2001) to also account for the force due to sea surface tilt and the surrounding sea ice in their drift model, where the effect of sea ice was analyzed in open water (concentration $<15 \%$ ), open pack ice (concentration between 15 and 90\%) and closed pack ice (concentration over 90\%). Lichey and Hellmer (2001) suggested that incorporation of sea-ice force into an iceberg drift model is essential as the presence of dense sea ice over a large area has the ability to entrap icebergs and collect a proportion of the wind and current momentum that is blocked by sea ice. This means that a proportion of wind and current energy is indirectly transferred to iceberg through pack ice given its large surface area, resulting in a more dominant influence of sea ice on the drift of ice islands when sea ice is present at high concentrations. A new iceberg drift model was developed later by Kubat and others (2005), which was built on available drift models (e.g. El-Tahan and others, 1983; Banke and Smith, 1984; Murphy and Anderson, 1986), but also included the vertical distribution of ocean currents over the keel depth of the icebergs to present a more realistic influence of currents. Their study also included a sensitivity analysis to examine the effect of various input parameters on the drift trajectory of icebergs, which were also compared against the field observations by Smith and Donaldson (1987). The authors stated that while ocean currents and waterline length had the most pronounced effect on iceberg drift velocity, the drift model was most insensitive to the water and air drag coefficients due to the fact that icebergs closely followed the average current velocity over keel depth.

In an observational study, Peterson and others (2009) studied the drift of a large ice island from the Petermann Glacier using a combination of satellite imagery and tracking beacons. The influence of sea-ice cover on the motion of the tracked ice island was found to be significant, given that the ice island was not able to drift into Nares Strait due to blockage or being dominated by the high concentration of sea ice, until a major wind event cleared the sea-ice cover letting the ice island escape from Petermann Fjord. Ice island drift was modeled by Crocker and others (2013) using the North American Ice Service iceberg drift and deterioration model with modified geometry to account for changes in the shape and size of the ice island. While their model resulted in a slightly better drift model than the CIS model, the authors stated that the altered ice island 
drift model was still poor due to the inaccuracy of estimated ocean currents.

An important component that contributes to the calibration and validation of a drift-forecasting model is a reliable estimation of the change in dimensions and mass of the ice feature over its drift time. This can be done through modeling the mechanisms that result in the deterioration of an ice feature. Job (1978) and El-Tahan and others (1987) identified several processes that contribute to the deterioration of icebergs, including melting due to buoyant vertical convection, melting due to forced convection from air and water, surface ablation due to the solar radiation, wave erosion and calving of overhanging slabs. While surface ablation is identified as a minor contributor to the overall deterioration of non-tabular icebergs (Savage, 2001), it has a great impact on the total deterioration of ice islands (Crocker and others, 2013). Some of the mechanisms mentioned earlier have been considered in the study by Crawford and others (2015) where the surface ablation of an ice island was modeled using energy fluxes calculated through the bulk aerodynamic approach and then compared against CIS models and a temperature index melt (TIM) model. The TIM model is a simple empirical model that provides the surface ablation rate as a function of air temperature, a variable that is reasonably easy to forecast (Hock, 2005). While the solar radiation term is ignored in this model, it is able to predict the surface ablation rate relatively well as surface energy fluxes are strongly correlated with the air temperature (Braithwaite and Olesen, 1993; Crawford and others, 2015).

The deterioration of ice islands can also be estimated through observed changes in their dimensions. Due to the harsh conditions and logistical difficulties of data collection in ice-prone environments, there are limited in situ data on the dimensions, geometry and thickness of ice islands. Halliday and others (2012) measured the rate of thinning, as well as the surface and basal ablation rates of an ice island offshore Labrador using ablation stakes and ground penetrating radar. Alternatively, the deterioration of ice islands (e.g. calving events and surface reduction) can be estimated through remote-sensing observations using the satellite images when no field data on the dimensions of large ice features are available (Crawford and others, 2018a). Due to the large extent and angular shape of ice islands, these ice features can easily be distinguished from pack ice or open water in satellite images. Although some satellite imagery have a low spatial resolution, the areal reduction in the surface of large ice islands can be monitored through the observed difference between the image acquisitions from various satellite systems such as MODIS and Envisat (Scambos and others, 2005; Peterson and others, 2009). While the amount of daylight and cloud cover may limit the use of these image analysis (optical) methods, spaceborne synthetic aperture radar (SAR) is capable of imaging ice features during times of low light and high cloud cover (Jeffries, 2002).

\section{Methods}

\subsection{Study site}

Beacons were deployed from the Canadian Coast Guard Ship (CCGS) Amundsen, a research icebreaker, during the Offshore Newfoundland Research Expedition (ONRE) from 17 April to 4 May 2015. The deployment of the tracking beacons took place on 29 April 2015 offshore northern Newfoundland, where a large ice island (most likely from the Petermann Glacier in NW Greenland) was detected in Landsat imagery at the NE entrance to the Strait of Belle Isle. At this time, the ice island was grounded near the southeastern coast of Labrador and locked in $9+/ 10$ th sea-ice concentration. The dimensions of the ice island were estimated to be $\sim 1.6 \mathrm{~km}$ in maximum waterline length (with $6 \%$ uncertainty) and $\sim 10 \mathrm{~m}$ in average freeboard; the latter was estimated using the hydrostatic balance for the parent ice island (Fig. 2).

\subsection{Tracking beacon deployments and characteristics of ice island fragments}

Four beacons (Canatec and Associates, Ltd) enclosed in waterproof, plastic cases were deployed by hand via the ship's helicopter on the ice island in a quadrilateral array 500-700 m apart from one another toward the center of ice island (Table 1). The beacons were secured to the ice with boards that had beds of nails in them, to prevent the beacons from being blown off the ice island by the wind. The ice-tracking beacons transmitted Universal Time Coordinated (UTC) time, internal temperature and latitude/longitude GPS readings via Iridium satellite to a data management website (with $1.8 \mathrm{~m}$ Circular Error Probable). Initially, the four beacons were remotely set to transmit data at 6-hour intervals during the time that the ice island was grounded. The ice island broke up into several fragments (Fig. 1) on 6 May 2015, which began to drift SW further into the Strait of Belle Isle. The four tracking beacons were then set to transmit hourly data and remained on the ice island fragments until the fragments melted (or experienced calving or rolling) (Table 1). The tracking beacons continued to transmit data as surface current drifter buoys, but this study only presents the analysis during the time that the beacons remained on the fragments. To determine whether the beacon was on the ice island or freely drifting in the ocean, diurnal variability in beacon temperatures was analyzed. While on ice, the beacon temperature records consistently displayed large diurnal variations. However, when the beacons fell into water, their temperature records reflected surface water temperature with minor fluctuations.

\subsection{Reduction in surface area}

The surface area, length and width of each ice island fragment in this study were estimated from the available (29 April 2015-21 July 2015) SAR images during the fragment drift, using Focus PCI Geomatics software (version 2013). These dimensions were interpolated between satellite observations based on the assumption that their reduction in size was linear. However, it is possible that the fragments may have undergone episodic calving between observations.

\subsection{Surface ablation}

The surface ablation of the ice island fragments was estimated using a TIM model, in which the surface melt rate is calculated by (Hock, 2003):

$$
V_{\mathrm{sa}}=D D F \sum P D D
$$

where $D D F$ (Table 2) represents the degree-day factor, which is a region-specific parameter that the TIM model is sensitive to (Crawford and others, 2015). Reported values of degree-day factors range from 2 to $11 \mathrm{~mm} \mathrm{~d}^{-1}{ }^{\circ} \mathrm{C}^{-1}$ for glaciers in various sites (Hock, 2003). This study uses an average of $4 \mathrm{~mm} \mathrm{~d}^{-1}{ }^{\circ} \mathrm{C}^{-1}$ for the degree-day factor (Table 2), which was estimated based on the assumption that the ice island fragments became completely melted (through surface and basal ablation) at the same time that the beacons fell into water. While the beacons could have fallen into the water due to the break-up or capsize of the fragments, this is unlikely given that the available SAR images 


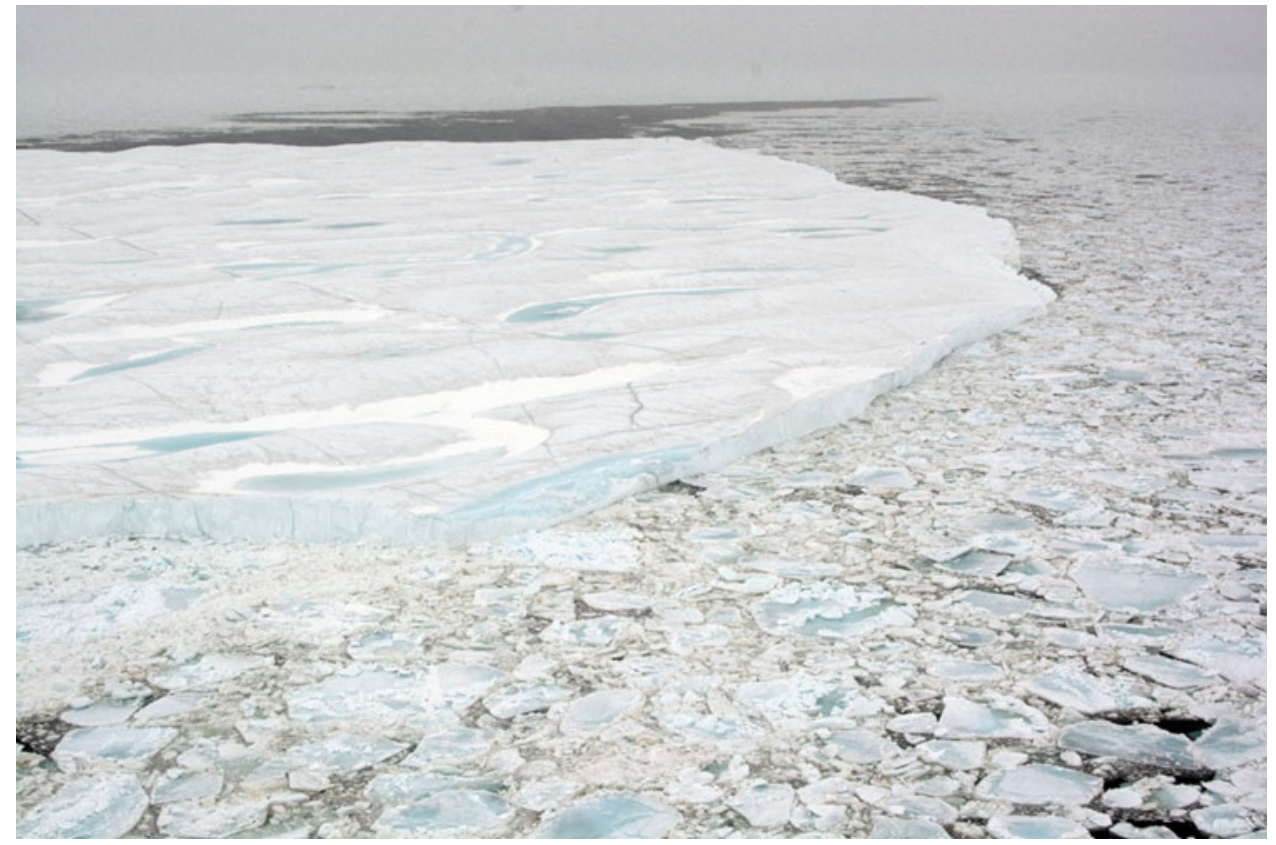

Fig. 2. The ice island in this study, shown surrounded by sea ice at the NE end of the Strait of Belle Isle on 29 April 2015.

Table 1. Summary of ice island tracking beacon deployments (times and locations where the beacons were first deployed) on a large ice island grounded at the NE end of the Strait of Belle Isle

\begin{tabular}{|c|c|c|c|c|}
\hline Beacon IMEI ${ }^{\mathrm{a}}$ (last four digits) & Time $\left(U_{T C} C^{b}\right)$ & Latitude $\left({ }^{\circ} \mathrm{N}\right)$ & Longitude $\left({ }^{\circ} \mathrm{W}\right)$ & Time on ice \\
\hline 6640 & 29 April 2015 21:32 & 52.01536 & 55.66191 & 29 April-25 June \\
\hline 1700 & 29 April 2015 21:25 & 52.0191 & 55.66693 & 29 April-25 June \\
\hline 2500 & 29 April 2015 22:14 & 52.02375 & 55.66017 & 29 April-24 June \\
\hline 5640 & 29 April 2015 21:12 & 52.01904 & 55.65343 & 29 April-22 July \\
\hline
\end{tabular}

anternational mobile equipment identity.

${ }^{\mathrm{b}}$ Coordinated universal time.

did not show any remaining fragments beyond the time we assumed the beacons fell into water. The variable $P D D$ in Eqn (1) represents the positive degree days, which is the sum of the daily mean positive air temperatures $\left(>0^{\circ} \mathrm{C}\right)$ during the analyzed period (Hock, 2003).

\subsection{Basal ablation}

The thinning rate through the base of the ice island $\left(V_{\mathrm{ba}}\right)$ was determined using the forced convection basal ablation model that was calibrated with ice island melt rate observations and recorded atmospheric and oceanic data, given by (Crawford, 2018):

$$
V_{\mathrm{ba}}=k\left|\vec{v}_{\mathrm{w}}(b)-\vec{u}\right|^{0.8}\left(\frac{T_{\mathrm{w}}(b)-T_{\mathrm{mi}}}{L^{0.2}}\right)
$$

where $k$ is an empirical coefficient (Table 2) given by Crawford (2018), $\vec{v}_{\mathrm{w}}(b)$ is the ocean current velocity at the keel depth, $u$ is the ice island fragment velocity, $T_{\mathrm{w}}(b)$ is the water temperature at the base of the fragment, $T_{\mathrm{mi}}$ is the melting temperature of the ice and $L$ is the length of the ice island fragment. The fragment velocity was calculated between successive beacon position/time records. The calculated values represent the velocity at the midpoint between these positions, so they were linearly interpolated in space and time back to the beacon record positions. The melting temperature of the ice was estimated using an empirical correlation to account for the ice melting point depression due to the interfacial salinity at the base of the ice island fragments (Løset, 1993; Kubat and others, 2007), given by Josberger (1978):

$$
T_{\mathrm{mi}}=T_{\mathrm{f}} \exp \left(-0.19\left[T_{\infty}-T_{\mathrm{f}}\right]\right)
$$

where $T_{\infty}$ indicates the ambient water temperature at a distance beyond the influence of the ice island fragment. It should be noted that $T_{\infty}$ and $T_{\mathrm{w}}(b)$ are effectively the same in our model given that the extracted ocean water temperature from CMEMS has a resolution of $1 / 12^{\circ}(\sim 9 \mathrm{~km})$. So the ambient water temperature at some distance away from the ice island fragments lies within the same gridpoint as the ice island where $T_{\mathrm{w}}(b)$ was extracted. $T_{\mathrm{f}}$ is the freezing temperature of the water, which was estimated as a function of the water salinity $(S)$ given by (Fujino and others, 1974):

$$
T_{\mathrm{f}}=-0.036-0.0499 S-0.000112 S^{2}
$$

The daily water salinity and potential temperature at different depth layers were extracted using Global Ocean Physics Reanalysis Glorys12v1 model from Copernicus Marine Environment Monitoring Service (CMEMS). Potential temperature was then adjusted based on the water pressure and salinity at each depth to calculate the actual water temperature. The velocity of ocean currents over the depth of ice island fragments was extracted from CMEMS Global Ocean $1 / 12^{\circ}$ Physics Analysis and Forecast model. The extracted data were all 
Table 2. Description and values of the parameters and variables

\begin{tabular}{|c|c|c|c|c|}
\hline $\begin{array}{l}\text { Parameter/ } \\
\text { variable }\end{array}$ & Description & Unit & Value & Reference \\
\hline$\rho_{\mathrm{a}}$ & Air density & $\mathrm{kg} \mathrm{m}^{-3}$ & 1.293 & Lichey and Hellmer (2001) \\
\hline $\overrightarrow{\vec{v}_{a}}$ & Wind velocity & $\mathrm{m} \mathrm{s}^{-1}$ & Interpolated from NARR & North American Regional Reanalysis \\
\hline$\rho_{\mathrm{w}}$ & Water density & $\mathrm{kg} \mathrm{m}^{-3}$ & 1025 & Crawford and others (2018b) \\
\hline $\overrightarrow{\vec{v}_{w}}$ & Mean current velocity & $\mathrm{m} \mathrm{s}^{-1}$ & Interpolated from CMEMS and averaged over the draft & $\begin{array}{l}\text { Copernicus Marine Environment } \\
\text { Monitoring Service }\end{array}$ \\
\hline$\rho_{\mathbf{s i}}$ & Sea-ice density & $\mathrm{kg} \mathrm{m}^{-3}$ & 900 & Turnbull and others (2017) \\
\hline$c_{\mathrm{a}}$ & Air form drag coefficient & - & $0.4^{\mathrm{a}}$ & Lichey and Hellmer (2001) \\
\hline$c_{\mathrm{w}}$ & Water form drag coefficient & - & 0.85 & Lichey and Hellmer (2001) \\
\hline$c_{\mathrm{da}}$ & Air skin drag coefficient & - & 0.00025 & Lichey and Hellmer (2001) \\
\hline$c_{\mathrm{dw}}$ & Water skin drag coefficient & - & 0.0005 & Lichey and Hellmer (2001) \\
\hline $\mathbf{\Omega}$ & Earth's angular speed & $\operatorname{rad~s}^{-1}$ & $7.27 \times 10^{-5}$ & \\
\hline$\phi$ & Ice island latitude & $\circ$ & Recorded by tracking beacons & \\
\hline$c_{\text {si }}$ & Sea-ice resistance coefficient & - & 1.0 & Lichey and Hellmer (2001) \\
\hline$A_{\text {ha }}$ & Surface area & $\mathrm{m}^{2}$ & Estimated from SAR imagery & \\
\hline$A_{\text {hw }}$ & Basal area & $\mathrm{m}^{2}$ & Equal to $A_{\text {ha }}$ for ice islands & \\
\hline$A_{\text {va }}$ & $\begin{array}{l}\text { Above water cross sectional } \\
\text { area }\end{array}$ & $\mathrm{m}^{2}$ & Estimated from sail width and height & \\
\hline$A_{\mathrm{vw}}$ & $\begin{array}{l}\text { Under water cross sectional } \\
\text { area }\end{array}$ & $\mathrm{m}^{2}$ & Estimated from keel width and height & \\
\hline$\vec{v}_{s i}$ & Sea-ice velocity & $\mathrm{m} \mathrm{s}^{-1}$ & Interpolated from CMEMS & $\begin{array}{l}\text { Copernicus Marine Environment } \\
\text { Monitoring Service }\end{array}$ \\
\hline$\vec{u}$ & Ice island velocity & $\mathrm{m} \mathrm{s}^{-1}$ & Estimated from the ice island observed location & \\
\hline$\vec{g}$ & Gravitational acceleration & $\mathrm{m} \mathrm{s}^{-2}$ & 9.81 & \\
\hline$\rho_{\mathbf{i}}$ & Ice island density & $\mathrm{kg} \mathrm{m}^{-3}$ & 873 & Crawford and others (2018b) \\
\hline$h_{\mathbf{i}}$ & Ice island thickness & $\mathrm{m}$ & $\begin{array}{l}\text { Estimated from ice island hydrostatic balance and ablation } \\
\text { models }\end{array}$ & Hock (2003) \\
\hline $\boldsymbol{V}_{\mathbf{i}}$ & Ice island volume & $\mathrm{m}^{3}$ & Estimated from ice island surface area and thickness & \\
\hline$L$ & Ice island length & $\mathrm{m}$ & Estimated from SAR imagery & \\
\hline$w$ & Ice island width & $\mathrm{m}$ & Estimated from SAR imagery & \\
\hline$h_{\mathrm{s}}$ & Ice island sail height & $\mathrm{m}$ & $\begin{array}{l}\text { Estimated from the difference between the ice island } \\
\text { thickness and keel depth }\end{array}$ & \\
\hline $\boldsymbol{h}_{\mathrm{k}}$ & Ice island keel depth & $\mathrm{m}$ & $\begin{array}{l}\text { Estimated from bathymetry data and ice island hydrostatic } \\
\text { balance }\end{array}$ & $\begin{array}{l}\text { National Oceanic and Atmospheric } \\
\text { Administration }\end{array}$ \\
\hline M & Ice island mass & $\mathrm{kg}$ & Estimated from ice island density and volume & \\
\hline DDF & Degree-day factor & $\mathrm{mm} \mathrm{d}^{-1}{ }^{\circ} \mathrm{C}^{-1}$ & 4 & \\
\hline$P D D$ & Positive degree days & ${ }^{\circ} \mathrm{C}$ & Estimated using NARR data & North American Regional Reanalysis \\
\hline$V_{\text {ba }}$ & Ice island base thinning rate & $\mathrm{m} \mathrm{s}^{-1}$ & Estimated from basal ablation model & Crawford (2018) \\
\hline$k$ & Bulk heat transfer coefficient & $\begin{array}{l}\mathrm{m}^{2 / 5} \mathrm{~S}^{-1 / 5} \\
\mathrm{c}^{-1}\end{array}$ & $1.3 \times 10^{-5}$ & Crawford (2018) \\
\hline$\vec{v}_{w}(b)$ & $\begin{array}{l}\text { Current velocity at the keel } \\
\text { depth }\end{array}$ & $\mathrm{m} \mathrm{s}^{-1}$ & Interpolated from CMEMS & $\begin{array}{l}\text { Copernicus Marine Environment } \\
\text { Monitoring Service }\end{array}$ \\
\hline$T_{\mathrm{w}}(b)$ & $\begin{array}{l}\text { Water temperature at the keel } \\
\text { depth }\end{array}$ & ${ }^{\circ} \mathrm{C}$ & Interpolated from CMEMS & $\begin{array}{l}\text { Copernicus Marine Environment } \\
\text { Monitoring Service }\end{array}$ \\
\hline$T_{\mathrm{f}}$ & Water freezing temperature & ${ }^{\circ} \mathrm{C}$ & Estimated from an empirical correlation & Fujino and others (1974) \\
\hline$T_{\infty}$ & Water temperature & ${ }^{\circ} \mathrm{C}$ & Interpolated from CMEMS & $\begin{array}{l}\text { Copernicus Marine Environment } \\
\text { Monitoring Service }\end{array}$ \\
\hline $\mathbf{S}$ & Water salinity & ppt & Interpolated from CMEMS & $\begin{array}{l}\text { Copernicus Marine Environment } \\
\text { Monitoring Service }\end{array}$ \\
\hline$T_{\mathrm{a}}$ & Air temperature & ${ }^{\circ} \mathrm{C}$ & Interpolated from NARR & North American Regional Reanalysis \\
\hline$c$ & Sea-ice concentration & - & Extracted from daily ice charts & \\
\hline $\boldsymbol{h}_{\mathrm{si}}$ & Sea-ice thickness & $\mathrm{m}$ & Extracted from daily ice charts & \\
\hline $\boldsymbol{P}_{\mathrm{s}}$ & Sea-ice strength threshold & $\mathrm{N} \mathrm{m}^{-1}$ & $660.9-14211.6$ & Lichey and Hellmer (2001) \\
\hline$P$ & Sea-ice compressive strength & $\mathrm{N} \mathrm{m}^{-1}$ & Estimated from Hibler's correlation & Hibler (1979) \\
\hline$P^{\star}$ & Sea-ice strength coefficient & $\mathrm{N} \mathrm{m}^{-2}$ & 20000 & Lichey and Hellmer (2001) \\
\hline$a$ & Sea-ice strength coefficient & - & 20 & Lichey and Hellmer (2001) \\
\hline
\end{tabular}

${ }^{\mathrm{a}} \mathrm{A} 40 \%$ higher value (0.56) was used for $c_{\mathrm{a}}$ to implicitly account for the effect of ocean surface waves (Smith, 1993; Keghouche and others, 2009).

interpolated to the fragments' observed locations and then integrated into Eqn (2) to allow for the calculation of basal ablation rates.

To present the total change in the thicknesses of ice island fragments over time, the cumulative vertical melt was estimated according to the above surface and basal ablation models and subtracted from the initial thickness. The initial thickness of the original ice island was estimated using the ice island hydrostatic balance at the time it started to drift. It was assumed that once the beacons started drifting, the ice island would have a draft slightly less (by $5 \mathrm{~m}$ ) than the shallowest water depth under the ice island.

\subsection{Mass calculation}

The mass of the fragments was calculated by:

$$
M=\rho_{\mathrm{i}} V_{\mathrm{i}}
$$

where $\rho_{\mathrm{i}}$ is the density of the ice island fragments. While the density of pure (bubble-free) ice is $\sim 917 \mathrm{~kg} \mathrm{~m}^{-3}$ (Enderlin and Hamilton, 2014), ice islands have lower density. This study uses the ice density of $873 \mathrm{~kg} \mathrm{~m}^{-3}$ for the fragments, as measured by Crawford and others (2018b). The variable $V_{\mathrm{i}}$ in Eqn (5) 


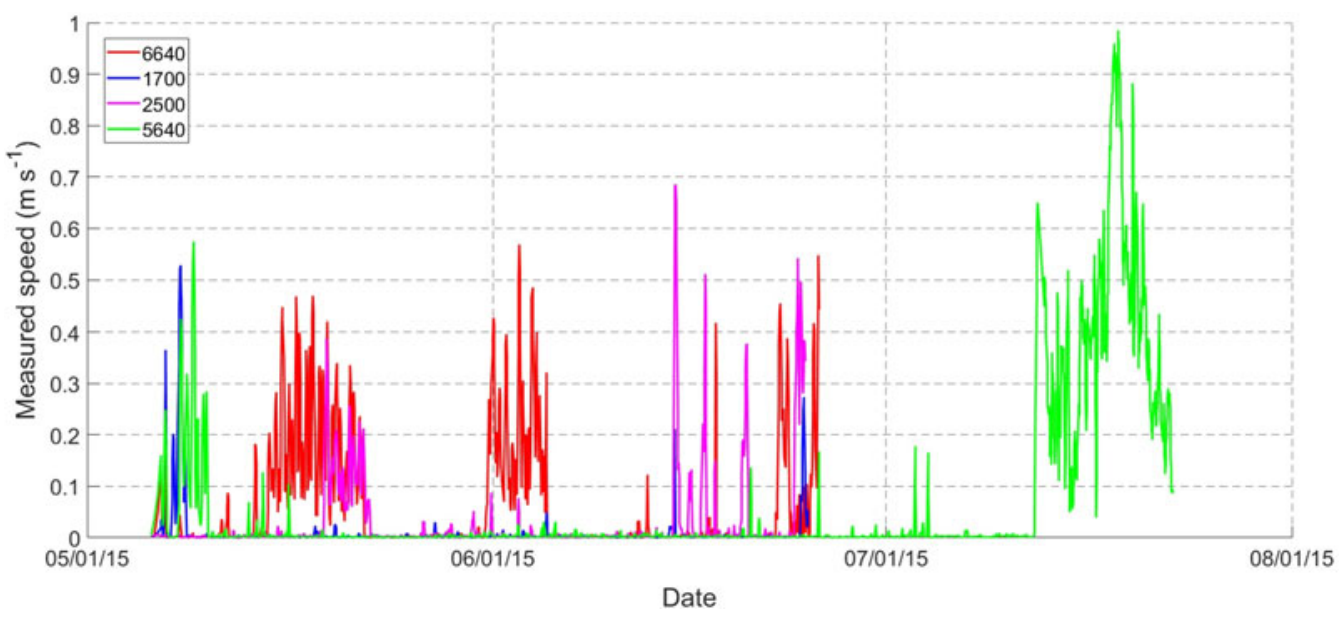

Fig. 3. Drift speeds of the four ice island fragments over their overall drift periods.

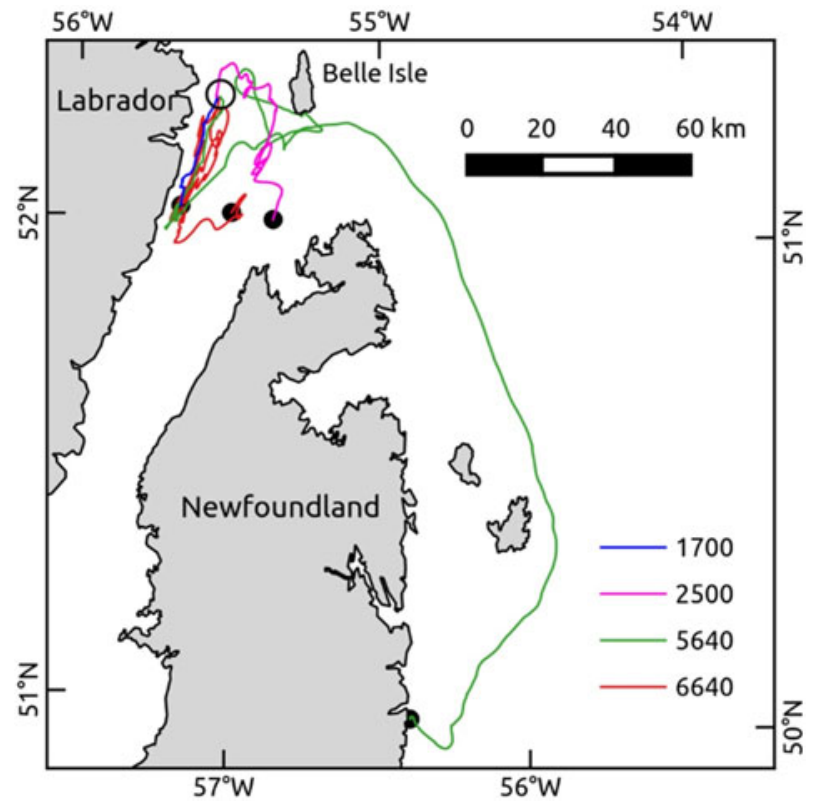

Fig. 4. Drift trajectories of the four ice island fragments over their drift periods. The open circle and black dots mark the start and ends of the recorded ice fragment trajectories, respectively.

represents ice island volume, calculated by:

$$
V_{\mathrm{i}}=A_{\mathrm{ha}} h_{\mathrm{i}}
$$

where $A_{\mathrm{ha}}$ and $h_{\mathrm{i}}$ represent the ice surface area and thickness of the ice island, respectively. The mass of each fragment was recalculated over time based on the interpolated surface area and modeled thickness.

\subsection{Drift equation}

The equation describing the drift of an ice island fragment is stated as (Lichey and Hellmer, 2001):

$$
M \frac{\mathrm{d} \vec{u}}{\mathrm{~d} t}=\vec{F}_{\mathrm{a}}+\vec{F}_{\mathrm{w}}+\vec{F}_{\mathrm{c}}+\vec{F}_{\mathrm{ss}}+\vec{F}_{\mathrm{si}}
$$

where $M$ is the mass of the ice island fragment. The five terms on the right side of Eqn (7) represent forces due to air drag, water drag, Coriolis effect, sea surface tilt, and sea ice, respectively. To evaluate these forces when the ice island fragments were not grounded, the atmospheric and oceanic data were extracted from available databases; the 3-hourly values for $10-\mathrm{m}$ wind velocity and 2-m air temperature were extracted from NARR dataset, however, sea surface height and sea-ice velocity were extracted from CMEMS Global Ocean 1/12 ${ }^{\circ}$ Physics Analysis and Forecast model. There were time periods in the extracted ocean currents data for the four fragments during which the ocean current velocities were missing. Therefore, the extracted data were linearly interpolated to fill out the gaps in the velocity of ocean currents. While the mass of the ice island was assumed to be constant in some drift models (e.g. Lichey and Hellmer, 2001), it varied in our model (Eqn (7)) to improve the model accuracy.

Air drag and water drag force (Eqn (7)) both on vertical walls and horizontal surfaces of the ice island fragment were calculated by (Smith and Banke, 1983):

$$
\begin{gathered}
\vec{F}_{\mathrm{a}}=\left[\frac{1}{2}\left(\rho_{\mathrm{a}} c_{\mathrm{a}} A_{\mathrm{va}}\right)+\rho_{\mathrm{a}} c_{\mathrm{da}} A_{\mathrm{ha}}\right]\left|\vec{v}_{\mathrm{a}}-\vec{u}\right|\left(\vec{v}_{\mathrm{a}}-\vec{u}\right) \\
\vec{F}_{\mathrm{w}}=\left[\frac{1}{2}\left(\rho_{\mathrm{w}} c_{\mathrm{w}} A_{\mathrm{vw}}\right)+\rho_{\mathrm{w}} c_{\mathrm{dw}} A_{\mathrm{hw}}\right]\left|\vec{v}_{\mathrm{w}}-\vec{u}\right|\left(\vec{v}_{\mathrm{w}}-\vec{u}\right)
\end{gathered}
$$

where $\rho_{\mathrm{a}}$ is the air density, $c_{\mathrm{a}}$ is the coefficient of resistance (form drag) for air and $c_{\mathrm{da}}$ is the air drag coefficient (skin drag). In Eqn (8), the vertical and horizontal areas of the ice island fragment exposed to air flow $\left(\vec{v}_{\mathrm{a}}\right)$ are denoted by $A_{\mathrm{va}}$ and $A_{\text {ha }}$, respectively. The parameters and variables in Eqn (9) are analogous to those in Eqn (8), but are indicated by the subscript $\mathrm{w}$ for water. Given the tabular shape of ice islands, the average current velocity $\left(\vec{v}_{\mathrm{w}}\right)$ in Eqn (9) was defined as the average of current velocity profile over the fragment draft. $A_{\mathrm{va}}$ and $A_{\mathrm{vw}}$ were estimated from the fragment length $(L)$, width $(W)$, sail height $\left(h_{\mathrm{s}}\right)$, and draft $\left(h_{\mathrm{k}}\right)$ by:

$$
A_{\mathrm{va}}=h_{\mathrm{s}} \frac{(L+W)}{2}
$$

$$
A_{\mathrm{vw}}=h_{\mathrm{k}} \frac{(L+W)}{2}
$$

The resulting force from the Coriolis effect and sea surface tilt are given by (Lichey and Hellmer, 2001):

$$
\vec{F}_{\mathrm{c}}=2 M \Omega \sin \phi \vec{k} \times \vec{u}
$$


Table 3. Drift characteristics of the ice island tracking beacons over their drift periods

\begin{tabular}{|c|c|c|c|c|c|c|}
\hline $\begin{array}{l}\text { Beacon } \\
\mid \mathrm{MEI}^{\mathrm{a}}\end{array}$ & $\begin{array}{l}\text { Total drift period } \\
\left(\text { UTC }^{\text {b }}\right)\end{array}$ & $\begin{array}{l}\text { Mean drift speed } \\
\left(\mathrm{m} \mathrm{s}^{-1}\right)\end{array}$ & $\begin{array}{l}\text { Max. drift speed } \\
\qquad\left(\mathrm{m} \mathrm{s}^{-1}\right)\end{array}$ & $\begin{array}{l}\text { Drift speed Std. Dev. } \\
\qquad\left(\mathrm{m} \mathrm{s}^{-1}\right)\end{array}$ & $\begin{array}{l}\text { Cumulative drift distance } \\
\qquad(\mathrm{km})\end{array}$ & $\begin{array}{l}\text { Net drift distance } \\
(\mathrm{km})\end{array}$ \\
\hline 6640 & 29 April-25 June & 0.18 & 0.57 & 0.12 & 274 & 32 \\
\hline 1700 & 29 April-25 June & 0.15 & 0.53 & 0.14 & 44 & 30 \\
\hline 2500 & 29 April-24 June & 0.17 & 0.69 & 0.15 & 124 & 38 \\
\hline 5640 & 29 April-22 July & 0.36 & 0.99 & 0.22 & 433 & 176 \\
\hline
\end{tabular}

anternational mobile equipment identity.

${ }^{b}$ Coordinated universal time.

${ }^{c}$ The drift speeds were estimated with high accuracy $\left( \pm 0.001 \mathrm{~m} \mathrm{~s}^{-1}\right)$ from the positional and time data transmitted by the tracking beacons.

Table 4. The estimated initial dimensions of the ice island fragments from SAR images

\begin{tabular}{llccc}
\hline $\begin{array}{l}\text { Beacon } \\
\text { IMEI }^{\text {a }}\end{array}$ & $\begin{array}{c}\text { Analyzed drift } \\
\text { period }\left(\text { UTC }^{\text {b }}\right)\end{array}$ & $\begin{array}{c}\text { Fragment } \\
\text { initial length } \\
(\mathrm{m})\end{array}$ & $\begin{array}{c}\text { Fragment } \\
\text { initial width } \\
(\mathrm{m})\end{array}$ & $\begin{array}{c}\text { Fragment initial } \\
\text { surface area } \\
\left(\mathrm{m}^{2}\right)\end{array}$ \\
\hline 6640 & 6 May-18 May & $1388(7 \%)^{\mathrm{c}}$ & $818(12 \%)$ & $724628(14 \%)$ \\
1700 & 6 May-30 May & $925(11 \%)$ & $604(17 \%)$ & $333300(20 \%)$ \\
2500 & 6 May-19 May & $1294(8 \%)$ & $855(12 \%)$ & $669586(14 \%)$ \\
5640 & 6 May-8 May & $831(12 \%)$ & $532(19 \%)$ & $288675(22 \%)$ \\
\hline
\end{tabular}

anternational mobile equipment identity.

${ }^{\mathrm{b}}$ Coordinated universal time.

${ }^{\mathrm{C}}$ The values in brackets indicate the relative uncertainties in the estimated dimensions. The initial thickness of all fragments was estimated to be $\sim 70 \mathrm{~m}$.

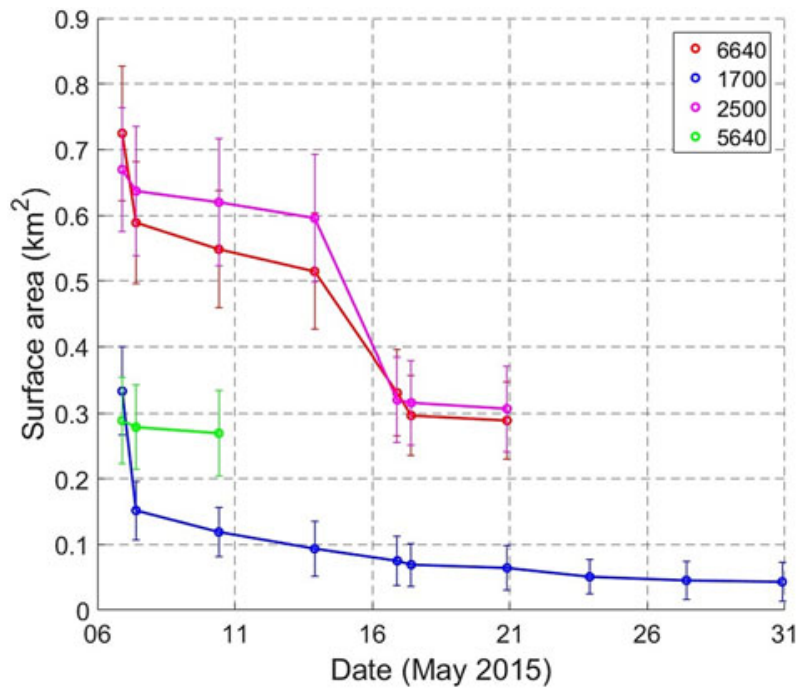

Fig. 5. The surface areas of the ice island fragments during the analyzed drift period, estimated from the SAR image acquisitions (marked with circles). The vertical bars show the error in the estimated values.

$$
\vec{F}_{\mathrm{ss}}=M \vec{g} \sin \alpha
$$

where $\Omega\left(7.27 \times 10^{-5} \mathrm{rad} \mathrm{s}^{-1}\right), \phi$ and $\vec{k}$ are the Earth's angular speed, the latitude of the ice island fragment and the unit vector perpendicular to the surface of Earth, respectively. In Eqn (13), $g$ is the acceleration due to gravity $9.81 \mathrm{~m} \mathrm{~s}^{-2}$ and $\alpha$ represents the sea surface slope. The sea surface tilt $(\sin \alpha)$ was estimated directly from CMEMS satellite altimetry data.

The force due to the surrounding sea ice was calculated using two different approaches; the residual method and Lichey and Hellmer's model (2001). From Eqn (7), the residual force $\left(\vec{F}_{\text {res }}\right)$ in the presence of sea ice was estimated by:

$$
\vec{F}_{\text {res }}=\vec{F}_{\mathrm{si}}+\vec{e}_{\mathrm{i}}=M \frac{\mathrm{d} \vec{u}}{\mathrm{~d} t}-\left(\vec{F}_{\mathrm{a}}+\vec{F}_{\mathrm{w}}+\vec{F}_{\mathrm{c}}+\vec{F}_{\mathrm{ss}}\right)
$$

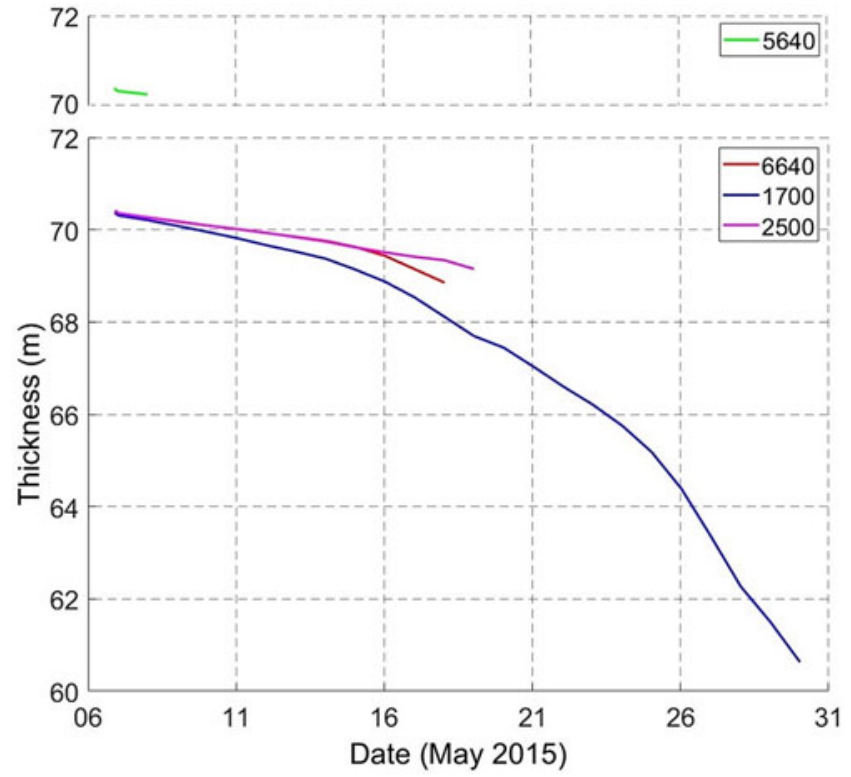

Fig. 6. The change in the thicknesses of the four ice island fragments during the analyzed drift period, estimated using the surface (TIM) and basal ablation models. The thickness change of fragment 5640 is plotted above the main graph due to the lines overlapping.

where $\vec{F}_{\text {si }}$ is the sea-ice force and $\vec{e}_{\mathrm{i}}$ is the error term that accounts for the error in the input data. In the presented analysis, it was assumed that the error term, $\overrightarrow{e_{i}}$, was sufficiently small, then $\vec{F}_{\text {res }} \sim \vec{F}_{\text {si }}$. This allowed us to estimate the contributions from sea ice based on the residual force. In the case that there was no sea ice present $\left(\vec{F}_{\mathrm{si}}=0\right)$, Eqn (14) still holds, but the residual force represents only the error term between the net force and the estimated force components. The residual force in open water is therefore given by:

$$
\vec{F}_{\mathrm{res}}=\vec{e}_{\mathrm{i}}=M \frac{\mathrm{d} \vec{u}}{\mathrm{~d} t}-\left(\vec{F}_{\mathrm{a}}+\vec{F}_{\mathrm{w}}+\vec{F}_{\mathrm{c}}+\vec{F}_{\mathrm{ss}}\right)
$$

The force due to the surrounding sea ice was calculated by (Lichey and Hellmer, 2001):

$$
\vec{F}_{\mathrm{si}}= \begin{cases}0 & C \leq 15 \% \\ \frac{1}{2} \rho_{\mathrm{si}} c_{\mathrm{si}} A_{\mathrm{si}}\left|\vec{v}_{\mathrm{si}}-\vec{u}\right|\left(\vec{v}_{\mathrm{si}}-\vec{u}\right) & 15 \%<C \leq 90 \% \\ -\left(\vec{F}_{\mathrm{a}}+\vec{F}_{\mathrm{w}}+\vec{F}_{\mathrm{c}}+\vec{F}_{\mathrm{ss}}\right) & C \geq 90 \% \text { and } P \geq P_{\mathrm{s}}\end{cases}
$$

where $\rho_{\mathrm{si}}$ is the density of sea ice, $c_{\mathrm{si}}$ is the coefficient of resistance for sea ice, assumed to be 1.0 (Bigg and others, 1997; Lichey and Hellmer, 2001), $A_{\mathrm{si}}$ is the estimated contact area between sea ice and the ice island fragment (defined as the product of sea-ice thickness and ice island waterline length; Lichey and Hellmer, 

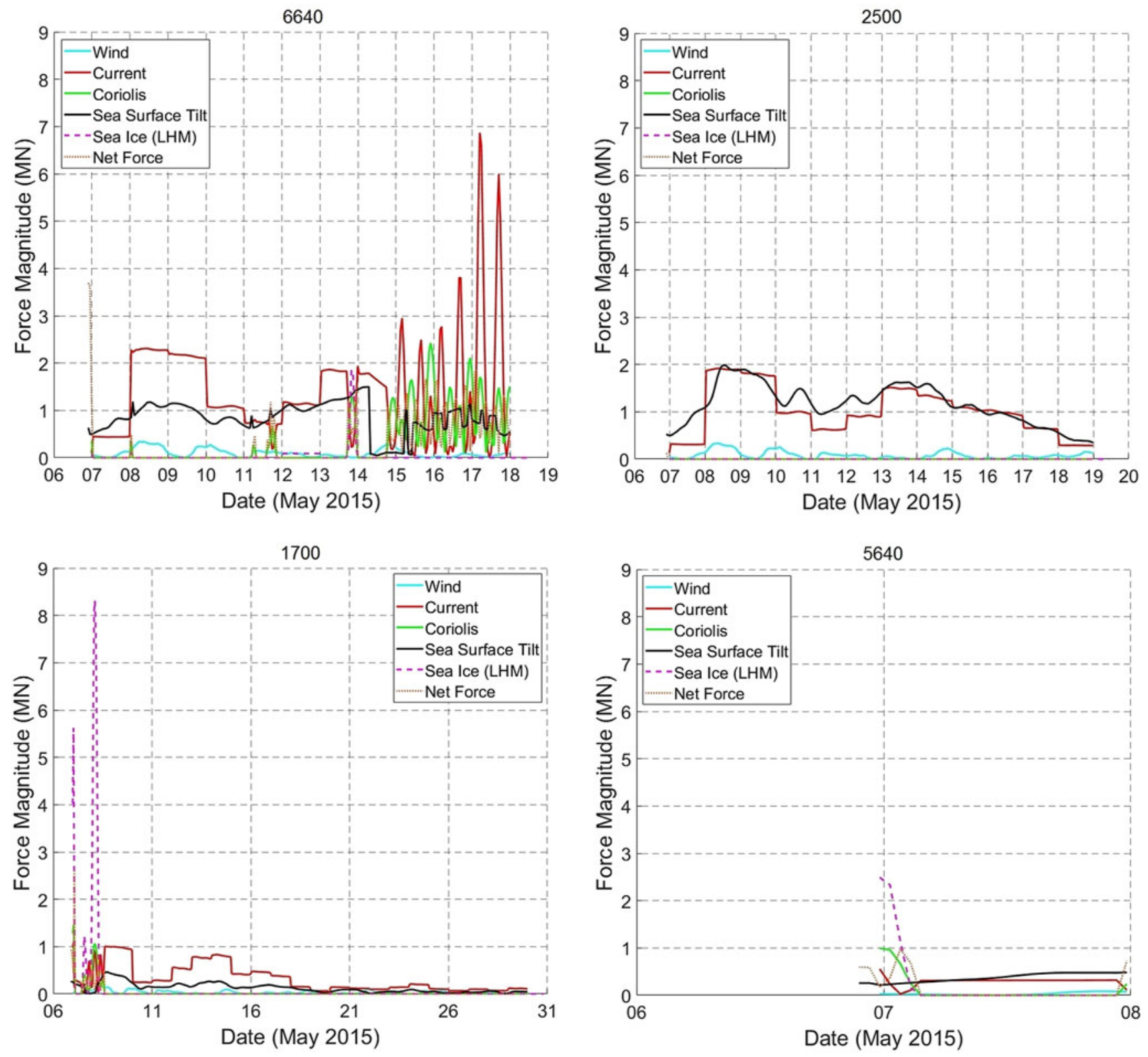

Fig. 7. The magnitudes of the forces caused by wind, currents, Coriolis deflection, sea surface tilt and surrounding sea ice on the ice island fragments tracked by beacons 6640,1700, 2500 and 5640. LHM indicates the estimation using Lichey and Hellmer's model (2001).

2001), $\vec{v}_{\mathrm{si}}$ is the sea-ice velocity and $C$ is the concentration of sea-ice cover in percent. According to Eqn (16), sea ice with concentrations $<15 \%$ are considered as open water and exert no force on the ice island fragment. However, for sea-ice concentrations between 15 and $90 \%$ (open drift), sea ice impose additional drag on the ice island. For concentrations over 90\% (close pack) where the sea-ice compressive strength $(P)$ is greater than its threshold value $\left(P_{\mathrm{s}}\right)$, sea-ice envelopes the ice island fragment causing it to drift at the sea-ice velocity. The sea-ice compressive strength can be estimated from its thickness $\left(h_{\mathrm{si}}\right)$ and concentration by (Hibler, 1979):

$$
P=P^{*} h_{\mathrm{si}} \mathrm{e}^{-a(1-C)}
$$

where $P^{\star}$ and $a$ are empirical coefficients with values of 20 $000 \mathrm{~N} \mathrm{~m}^{-2}$ and 20, respectively (Lichey and Hellmer, 2001). While Eqn (16) presents the sea ice forcing for different sea-ice concentrations, only the relationships associated with open water and open drift were used in this study as the concentration of sea ice in the vicinity of ice island fragments during the analyzed period were never beyond $90 \%$. Sea-ice concentration and thickness were extracted manually from the CIS daily ice charts and cross-checked against the SAR images at the location of the ice island fragments over their drift period. A summary of all the parameters and variables used in this study, along with their values, is given in Table 2.

\subsection{Sensitivity analysis}

While commonly used values of skin and form drag coefficients for air and water $\left(c_{\mathrm{da}}=0.00025, c_{\mathrm{dw}}=0.0005, c_{\mathrm{a}}=0.4\right.$, and $c_{\mathrm{w}}=0.85$ ) were used in this study (Table 2), it is important to examine how sensitive the residual sea-ice force results are to a change in these coefficients. Due to the roughness variation in the surfaces, bases and walls of the ice island fragments, the skin drag coefficients were varied between 0.00025 and 0.008 , while the form drag coefficient values ranging from 0.05 to 2 were tested. These values were selected to account for the 

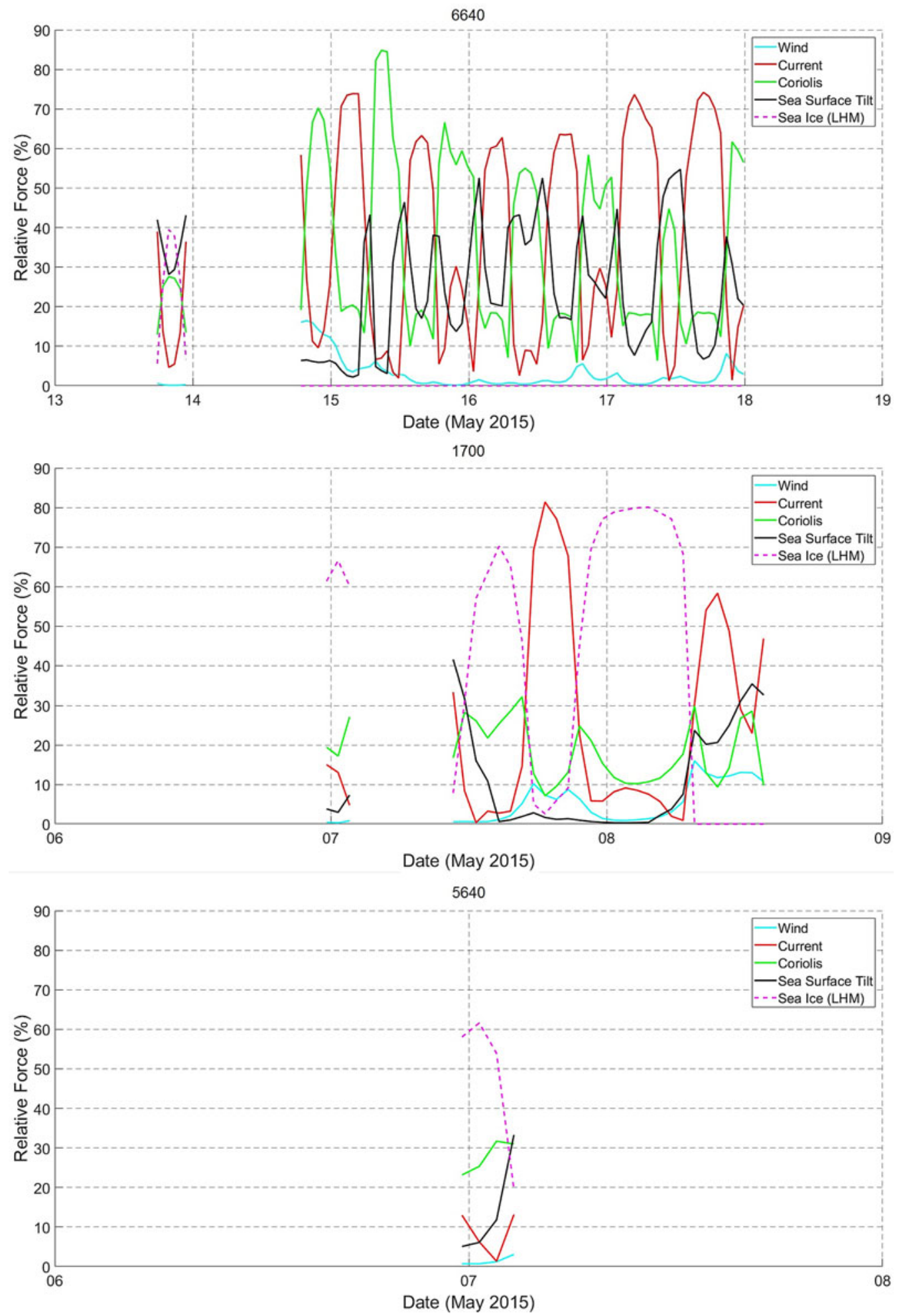

Fig. 8. The relative contributions of the forces caused by wind, currents, Coriolis deflection, sea surface tilt and surrounding sea ice to the overall drift of the ice island fragments tracked by beacons 6640,1700 and 5640 during the time periods that the fragments were drifting.

variation among the reported air/water drag coefficients on icebergs in other studies (e.g. Lichey and Hellmer, 2001; Kubat and others, 2005; Eik, 2009; Keghouche and others, 2009; Rackow and others, 2017), where values in the ranges of $0.00025-0.0025,0.0005-0.0055,0.1-2$ and $0.05-1.5$ were used for the air skin drag, water skin drag, air form drag and water form drag coefficients, respectively. To examine the individual influence of a varying drag coefficient, the other three coefficients were fixed at the nominal values mentioned earlier. These values were integrated into the residual sea-ice force model (Eqn (14)) to examine which of these four drag coefficients the model is most sensitive to.

Due to the uncertainty in the estimated masses and ocean currents, the sensitivity analysis was also performed to study the residual sea-ice force results to the variation of ice island fragments' masses, as well as the mean ocean currents speed and direction. Given that the dimensions of the fragments were estimated from satellite imagery data with resolution of $100 \mathrm{~m}$, the propagated 
error for mass was estimated and integrated into the sensitivity analysis. Also, the mean error in the magnitudes (speed) and directions of surface currents from CMEMS Global Ocean $1 / 12^{\circ}$ Physics Analysis and Forecast model was reported to be $0.08 \mathrm{~m} \mathrm{~s}^{-1}$ and $7.2^{\circ}$, respectively (Lellouche and others, 2018). Assuming the same error for the currents in different layers beneath the water surface, the residual forces (Eqn (7)) were calculated using the estimated average error in speeds $\left( \pm 0.08 \mathrm{~m} \mathrm{~s}^{-1}\right.$; high and low $)$ and directions $\left( \pm 7.2^{\circ}\right.$; high and low) of the currents to evaluate the model sensitivity to the error in the CMEMS ocean currents.

\section{Results}

This section presents the drift speeds (Fig. 3), directions (Fig. 4) and statistics (Table 3) of the four ice island fragments over the time periods that they were tracked by beacons. Diurnal variability in beacon temperatures showed that beacons 6640, 1700 and 2500 remained on the ice island fragments until 24-25 June 2015, however, beacon 5640 tracked the ice island fragment until 22 July 2015 when it broke up (Table 1).

Figure 4 shows the drift trajectories of the ice islands fragments during the drift periods given in Table 3. The four ice island fragments initially drifted in a looping pattern after break-up, and then one of the ice island fragments (beacon 5640) drifted to the SE side of the Northern Peninsula of Newfoundland. The drift of the ice island fragments back and forth NE-SW in the NE end of the Strait of Belle Isle was attributed to tidal currents by comparing the fluctuations in the drift velocities against the oscillation periods of tidal and inertial currents. Figure 4 along with the ratio of the net drift distance to the total drift distance (Table 3) revealed that while beacon 6640 experienced the most pronounced looping pattern, beacons 1700 drifted in a fairly straight direction toward the SW of the Strait of Belle Isle. The slight difference in the trajectories of ice island fragments upon break-up is most likely associated with their dimensions and masses which are important variables in the drift equation, Eqn (7). Fragment 5640, which was the smallest of the four fragments, drifted about a month more than the other fragments and the furthest from its original location (Fig. 4). The different drift directions of ice island fragments could also be associated with their orientations with respect to ocean current form drag, which is an important contributor to the overall drift of the fragments.

\subsection{Areal extent and thickness reduction}

The initial dimensions of the four ice island fragments after the breakup event of the original ice island are given in Table 4 . The initial surface areas of the fragments, estimated from the SAR imagery, ranged between 288675 and $724628 \mathrm{~m}^{2}$ (Fig. 5). SAR imagery resolution is nominally $100 \mathrm{~m}$, and the reported mean error in fragment areas using various methods of digitization ranged between 2.5 and 5.3\% (Crawford and others, 2018a, 2018b). Using the bathymetry data (extracted from ETOPO1 Global Relief Model, National Oceanic and Atmospheric Administration), the shallowest depth of water at the location of the ice island was $65 \mathrm{~m}$, so the initial draft was assumed to be slightly less, $\sim 60 \mathrm{~m}$, to account for the irregularities in the base of the ice island. Using hydrostatic balance for the parent ice island and assuming sea water density of $1025 \mathrm{~kg} \mathrm{~m}^{-3}$ and glacial ice density of $873 \mathrm{~kg} \mathrm{~m}^{-3}$ (Table 2), the total thickness of $\sim 70 \mathrm{~m}$ was estimated (Fig. 6). From the ice island initial thickness and draft, an average initial freeboard of $\sim 10 \mathrm{~m}$ was estimated and this appeared reasonable when compared against the photos of the ice island taken during the field expedition. The reduction in the areal extent and thickness of the ice island fragments are

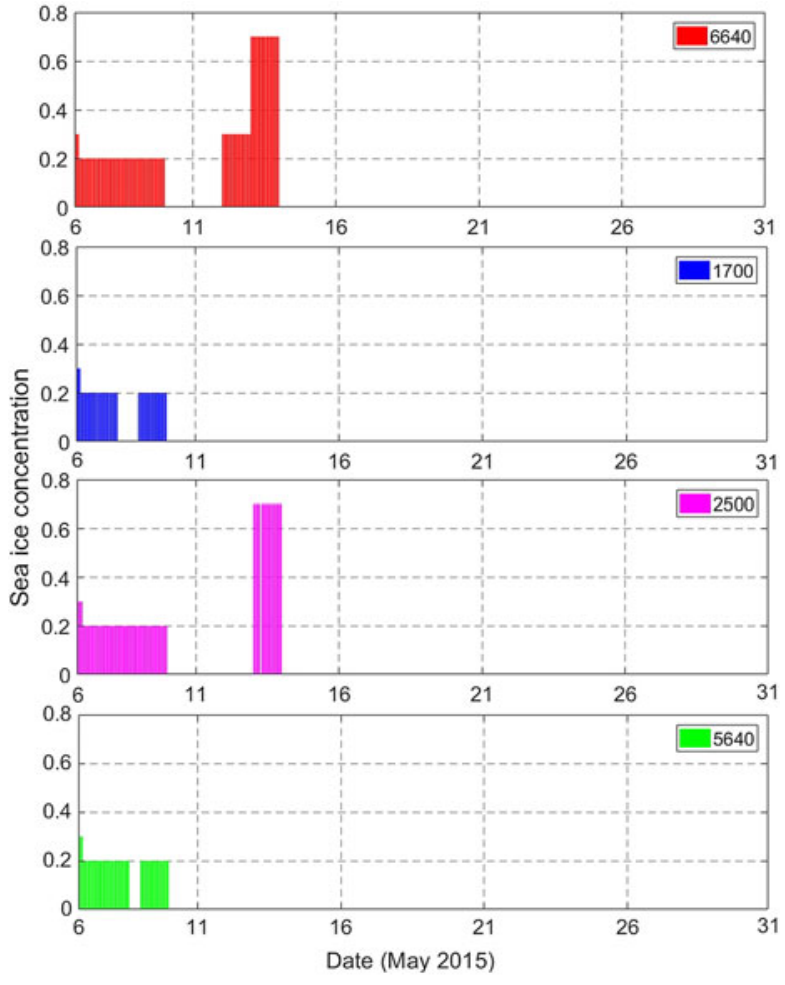

Fig. 9. The concentration of sea ice surrounding the four ice island fragments during the analyzed drift periods, obtained from CIS daily ice charts.

presented in Figures 5 and 6, respectively. The thickness melt models revealed that basal ablation was, on average, the main contributor to the overall reduction in the thickness of the ice island fragments, accounting for $52-94 \%$ of the total vertical melt rate. This is in agreement with the results of a Petermann ice island deterioration study by Crawford (2018), in which basal ablation was responsible for $73 \%$ of the total melt between November 2015 and September 2016.

\subsection{Atmospheric and oceanic forces}

The magnitudes and the relative contributions of the forces caused by wind, currents, Coriolis deflection, sea surface tilt and surrounding sea ice to the overall drift of the ice island fragments are presented in Figures 7 and 8, respectively. While the tracking beacons provided data on the locations of the ice island fragments over a longer period of time, the force analysis was narrowed down to the time periods in which the reanalysis data and satellite images of ice island fragments were simultaneously available (Figs $7,8,10$ ). Also, any grounded periods were removed from subsequent analysis (Figs 8,10 ), which resulted in removing the whole analysis for fragment 2500 as it was grounded for extended periods of time over the period analyzed in this study (Figure 11).

Figure 7 shows that forces due to ocean currents and sea surface tilt were found to dominate the other forces over the time periods presented in Table 4, except when sea ice was present at medium-high concentrations in the proximity of the fragments, or when the fragments drifted at higher speeds. The analysis of the relative contributions of the forces to the drift of the fragments (Fig. 8) revealed that when the sea ice exceeded a concentration of $20 \%$, it had the most pronounced effect on the drift of these fragments. The analysis of the relative contribution (Fig. 8) and the average magnitude (Table 5) of the forces over the analyzed drift periods of the ice island fragments suggest that the force caused by the wind had minimal effects on the overall drift of 

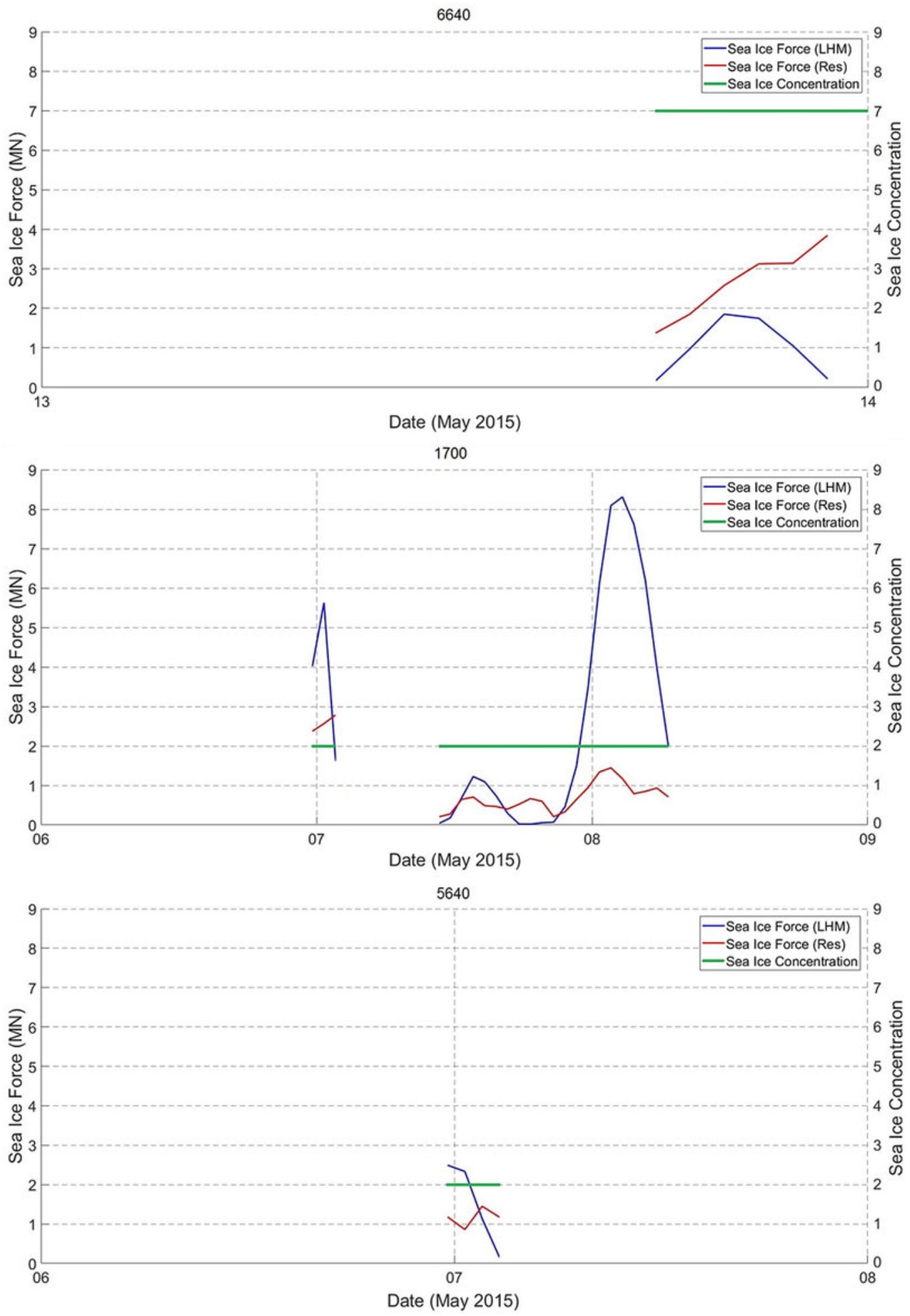

Fig. 10. Sea-ice force magnitudes on the ice island fragments tracked by beacons 6640, 1700 and 5640, calculated using a residual approach (Turnbull and others, 2017) and Lichey and Hellmer's model (2001). The second $y$-axis (on the right) indicates the sea-ice concentration out of 10 (green lines) in the vicinity of the ice island fragments. The residual ice force magnitudes were only presented for the drifting periods when sea ice was present.

the four fragments, and that Coriolis force was only significant when drift speeds were high. Given that sea ice was only present during the first few days of each fragment's drift and gave way to open water for much of the remainder of the analyzed drift (Fig. 9), the sea ice exerted no force on the ice island fragments for the majority of their observed drift periods (Fig. 7). Therefore, the sea-ice force analysis was only performed during sea-ice cover presence (Fig. 10). This analysis shows that the trend over time in the sea-ice force calculated from the residual approach (Eqn (14)) were generally similar to the rise and fall of the sea-ice force calculated from Lichey and Hellmer's model (2001) (Fig. 10). However, the values of sea-ice force magnitudes from Lichey and Hellmer's model (2001) were different from the ones obtained from the residual approach.

\section{Discussion}

The fact that ocean currents generally contributed the most to the drift of the ice island fragments is in agreement with other studies (e.g. Keghouche and others, 2009). This is expected given that a 
Table 5. The statistical analysis of the force magnitudes over the analyzed drift periods of the ice island fragments

\begin{tabular}{|c|c|c|c|c|c|c|c|c|c|c|c|c|c|c|c|c|c|c|}
\hline \multirow[b]{2}{*}{ Beacon IMEI $^{\mathrm{a}}$} & \multicolumn{3}{|c|}{$\begin{array}{l}\text { Wind force } \\
\text { (MN) }\end{array}$} & \multicolumn{3}{|c|}{$\begin{array}{l}\text { Current force } \\
\text { (MN) }\end{array}$} & \multicolumn{3}{|c|}{$\begin{array}{l}\text { Coriolis force }{ }^{b} \\
\text { (MN) }\end{array}$} & \multicolumn{3}{|c|}{$\begin{array}{l}\text { Sea surface tilt force } \\
\text { (MN) }\end{array}$} & \multicolumn{3}{|c|}{$\begin{array}{c}\text { Sea ice force }{ }^{c} \text { (Res.) } \\
(M N)\end{array}$} & \multicolumn{3}{|c|}{$\begin{array}{c}\text { Sea ice force } \\
\left(\text { LHM }^{\mathrm{d}}\right) \\
(\mathrm{MN})\end{array}$} \\
\hline & Rng. & M. $^{f}$ & Std. ${ }^{g}$ & Rng. & M. & Std. & Rng. & M. & Std. & Rng. & M. & Std. & Rng. & M. & Std. & Rng. & M. & Std \\
\hline \multirow[t]{2}{*}{6640} & 0.00 & 0.10 & 0.09 & 0.02 & 1.39 & 1.06 & 0.11 & 0.89 & 0.56 & 0.05 & 0.84 & 0.33 & 1.38 & 2.59 & 0.83 & 0.07 & 0.78 & 0.74 \\
\hline & 0.34 & & & 6.87 & & & 2.42 & & & 1.50 & & & 3.85 & & & 1.85 & & \\
\hline \multirow[t]{2}{*}{1700} & 0.00 & 0.03 & 0.03 & 0.00 & 0.32 & 0.28 & 0.02 & 0.45 & 0.40 & 0.01 & 0.12 & 0.10 & 0.20 & 0.92 & 0.72 & 0.02 & 2.65 & 2.87 \\
\hline & 0.17 & & & 1.10 & & & 1.45 & & & 0.46 & & & 2.78 & & & 8.31 & & \\
\hline \multirow[t]{2}{*}{2500} & 0.00 & 0.09 & 0.08 & 0.13 & 1.02 & 0.50 & - & - & - & 0.35 & 1.15 & 0.42 & - & - & - & 0.00 & 0.00 & 0.00 \\
\hline & 0.33 & & & 1.92 & & & - & & & 1.99 & & & - & & & 0.00 & & \\
\hline \multirow[t]{2}{*}{5640} & 0.00 & 0.03 & 0.03 & 0.03 & 0.29 & 0.10 & 0.24 & 0.62 & 0.37 & 0.22 & 0.37 & 0.09 & 0.74 & 1.08 & 0.28 & 0.16 & 1.53 & 1.10 \\
\hline & 0.08 & & & 0.56 & & & 0.99 & & & 0.48 & & & 1.45 & & & 2.49 & & \\
\hline
\end{tabular}

International mobile equipment identity.

${ }^{\mathrm{b}}$ Coriolis force was only analyzed during the time periods that the fragments were drifting.

'Sea-ice force was only analyzed during the time periods that the fragments were drifting and sea ice was present in the vicinity of ice island fragments.

dLichey and Hellmer's model (2001).

${ }^{\text {e }}$ Range.

${ }^{\mathrm{g}}$ Standard deviation.

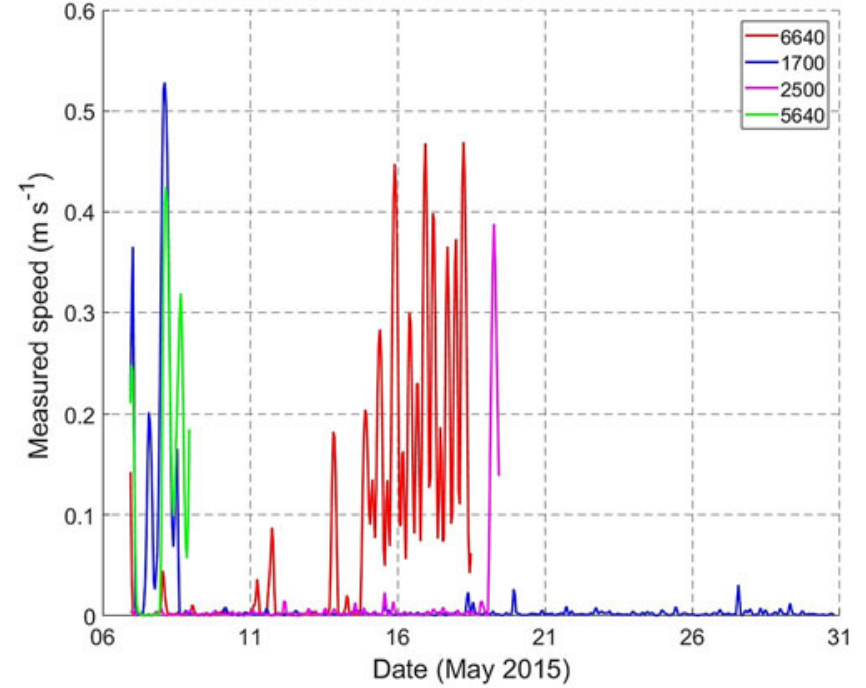

Fig. 11. Drift speeds of the four ice island fragments over the analyzed drift periods.

large portion of ice island fragments (their keel) is exposed to water currents at different depths. Also, given the significant difference in the density of air and ocean water, it is reasonable that the air drag played a minimal role in the overall drift of the four ice island fragments (Fig. 8). A comparison between the force magnitude due to the Coriolis effect (Fig. 7) and the drift speeds of the ice island fragments over the analyzed drift periods (Fig. 11) revealed that the Coriolis force was significant when the ice island fragments drifted at higher speeds. The dominant influence of sea surface tilt force in Figure 7 is most likely attributed to the mean dynamic ocean topography, given that atmospheric pressure gradient is only an important factor in sea surface height for large fragments (Turnbull, 2010), and that the tides are predominantly semidiurnal. While the overall force on the ice island fragments were influenced the most by ocean currents in open water, the ocean currents had a minor contribution in the presence of sea ice (Fig. 8). This indicates that sea ice most likely collected a proportion of wind and current momentum (Lichey and Hellmer, 2001) and, when present at high enough concentrations, played a more important role than currents in the drift of the ice island fragments.

The sea-ice force on the ice island fragments estimated from the residual approach (Eqn (14)) differed in magnitude from the sea-ice force magnitudes that were calculated by Lichey and
Hellmer's model (2001) as evident in Figure 10. The disagreement between the sea-ice force magnitudes from the two models is most likely associated with the errors in the reanalysis data, specifically the CMEMS ocean currents. This can be observed for fragment 6640 in Figure 12 during the times that sea ice was not present in the vicinity of the ice island fragment. The residual force during these time periods (Eqn (15)) indicate the existing error in the model, which is most likely associated with the error in CMEMS ocean currents. The sea-ice force from Lichey and Hellmer's (2001) model in medium sea-ice concentrations (Eqn (16)), which is the case for the drift periods analyzed in this study, is independent of the ocean currents. The accuracy of the residual approach in this study, however, rests upon fairly accurate estimation of ocean currents, given that the other forces are relatively well-constrained. While the ocean surface currents can sometimes be reasonably estimated from the wind conditions, the currents may vary significantly with depth. Turnbull and others (2017) used drifter buoys to directly measure the surface currents in the vicinity of the tracked ice floes, but the ocean currents in this study were extracted from CMEMS current data, which generally overestimate the measured current speed and could be wrong by $180^{\circ}$ in azimuth (Brickman and Drozdowski, 2012). A small error in the ocean current estimate could make a large difference to the residual sea-ice force (Eqn (14)). Therefore, an accurate estimation of ocean currents at different depths is essential to reliably estimate the ocean current force (and consequently residual sea-ice force). The different sea-ice force records from the two models may also be explained by the fact that Lichey and Hellmer's (2001) model (Eqn (16)) assumes that sea-ice force is not dependent on sea-ice concentration between concentrations of 15 and $90 \%$. This is likely a limitation of Lichey and Hellmer's model as sea-ice concentration is an important factor that influences the sea-ice force.

The residual approach to determine sea-ice force on ice island drift (Eqn (14)) is predicated on the assumption that the drift model accurately captures the behavior of ice island drift when there is no sea ice present. The residuals during periods of open water (Eqn (15) and Figure 12) indicate that this assumption was not met and therefore, it is likely that a component of the sea-ice force reported here is due to the error in the input data. Results should, therefore, be interpreted with caution until the input data can be improved. The presented model did not account for other forces (e.g. due to waves and atmospheric pressure gradient) in the drift equation (Eqn (7)) due to their insignificant influence on the drift of the ice island fragments analyzed in this study. Rackow and others (2017) stated that while the wave 


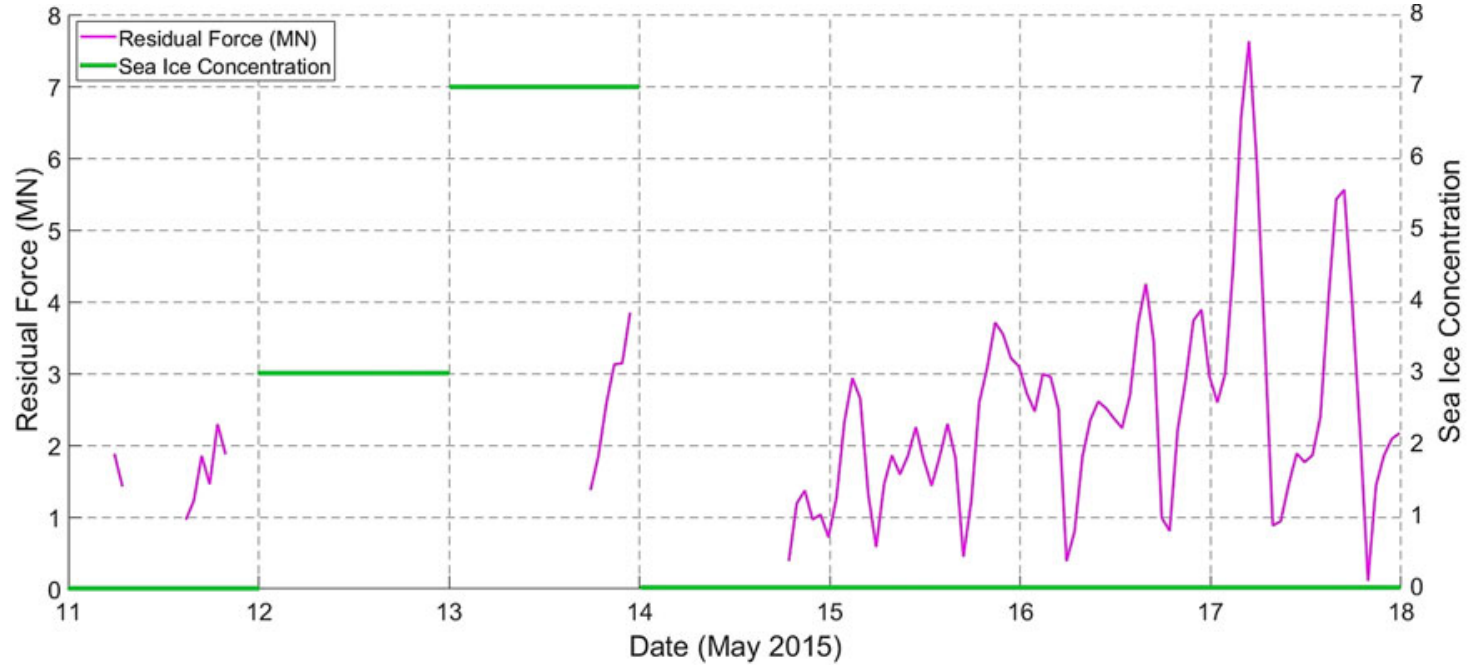

Fig. 12. Residual force magnitudes on the ice island fragment tracked by beacon 6640 over the analyzed drift periods in open pack ice and open water. The second $y$-axis (on the right) indicates the sea-ice concentration out of 10 (green lines) in the vicinity of the ice island fragment.
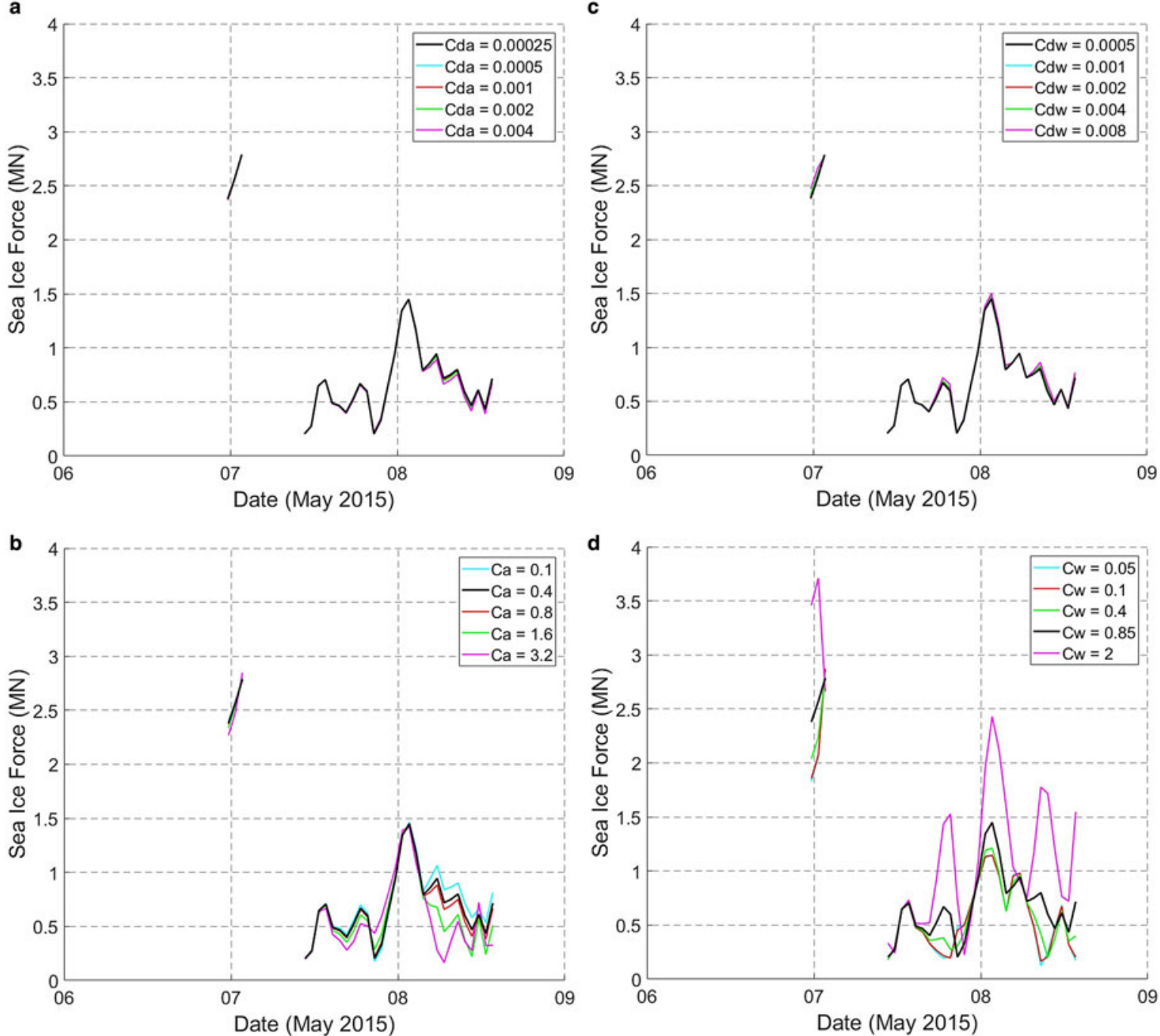

Fig. 13. The residual sea-ice force magnitude on the ice island fragment tracked by beacon 1700 , calculated using a residual approach (Turnbull and others, 2017) with varying skin $\left(c_{\mathrm{da}}\right.$ and $\left.c_{\mathrm{dw}}\right)$ and form $\left(c_{\mathrm{a}}\right.$ and $\left.c_{\mathrm{w}}\right)$ drag coefficient values for air $(\mathrm{a}, \mathrm{b})$ and water $(\mathrm{c}, \mathrm{d})$. Bold lines (in black) indicate the nominal values used in the study. The residual ice force magnitudes were only presented for the drifting periods when sea ice was present.

force is damped in high (over $40 \%$ ) concentration of sea ice, it could generate a more significant force on large ice islands when the concentration of sea ice is $<40 \%$. In this study, the wave force was not calculated due to the uncertainties in its formulation (Rackow and others, 2017); however, the model implicitly accounted for the effect of ocean surface waves by using a 


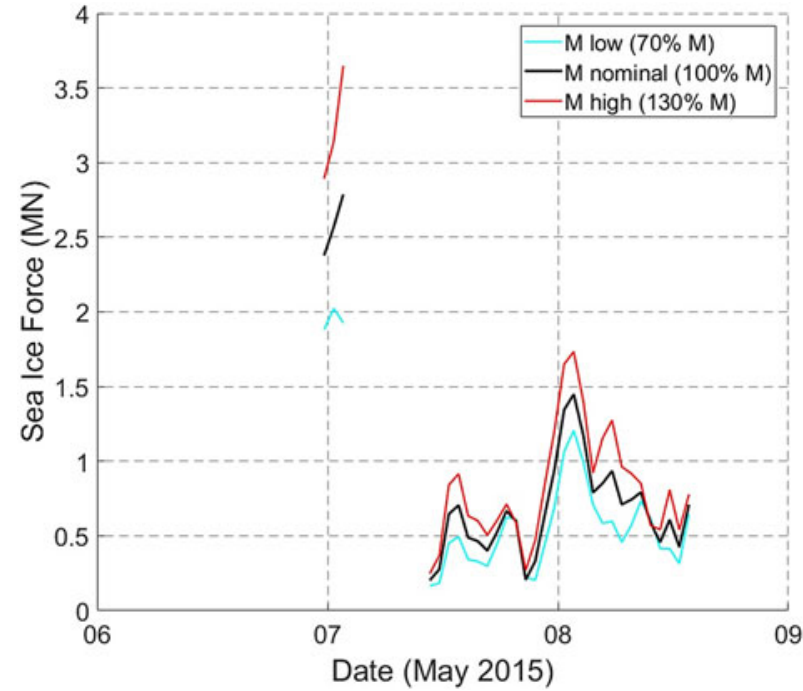

Fig. 14. The residual sea-ice force magnitude on the ice island fragment tracked by beacon 1700, calculated using a residual approach (Turnbull and others, 2017) with varying fragment masses. Bold lines (in black) indicate the nominal values used in the study. The residual ice force magnitudes were only presented for the drifting periods when sea ice was present.

$40 \%$ higher value for the wind form drag coefficient, since waves are most often in the same direction as wind (Smith, 1993; Keghouche and others, 2009). However, the modeled wind drag force (which also accounted for the effect of waves) had a minor contribution to the overall force on the fragments (Fig. 8), so wave force was probably not a significant factor. The force due to the atmospheric pressure gradient was also not likely a significant factor on the ice island fragments in this study as they were too small to cross surface isobars. This force, however, should be considered for significantly larger ice islands (Turnbull, 2010).

\subsection{Sensitivity analysis}

While the sensitivity analysis of the sea-ice force model (Eqn (14)) was performed on all of the four ice island fragments, only one fragment (1700) is presented here as the results for the other three fragments were similar. The sensitivity analysis revealed that out of the four drag coefficients, the sea-ice force magnitudes on the ice island fragments were most sensitive to the water form drag coefficient, followed by the air form drag coefficient. The force records from the residual approach (Turnbull and others, 2017) also revealed that the sea-ice force magnitudes were almost insensitive to varying the skin drag coefficients for both air and water (Figs 13a, c). These results are expected given that the values of skin drag coefficients are significantly lower than form drag coefficients and that higher proportions of the fragments' walls were exposed to water than to air. Therefore, one could expect that varying water drag coefficients would have a greater influence on the total force on the fragments and consequently on the sea-ice force magnitudes estimated from the residual approach. The force magnitudes (Fig. 13) also revealed that while the sea-ice force magnitudes increased as the water drag coefficients were increased, the sea-ice force decreased with the air drag coefficients. This indicates that the direction of the water drag force mostly opposed the sea-ice force directions. The drag force due to the wind, however, was mainly in the same direction as the sea-ice force directions.

The sensitivity of the presented residual force model to the mass of the fragments and ocean currents was also studied to examine the importance of the uncertainty in these variables. Given the estimated range for the error in the surface area of the ice island fragments (14-22\% as per Table 4), and assuming a larger error in the thickness of the fragments $(\sim 25 \%)$ due to the fact that they were estimated from empirical/calibrated correlations with several input parameters/variables (Eqns (1-4)), a propagated uncertainty of $\sim 30 \%$ for the mass was estimated and included in the sensitivity analysis (Fig. 14). This identified mass of the fragments as an important variable that influences the residual force results. The analysis of the sea-ice forces under the influence of varying ocean currents showed that the residual sea-ice force results were the most sensitive to error in the ocean current direction (Fig. 15b) and speed (Fig. 15a), when compared to the results for varying drag coefficients (Fig. 13). This indicates the importance of an accurate estimation of the ocean current velocity for a reliable sea-ice force model (Eqn (14)). When the error in the direction of the extracted ocean currents is taken into account for fragment 1700 , it is revealed that the residual sea-ice force (red and cyan lines in Fig. 15b) is well in agreement with the sea-ice force from Lichey and Hellmer's model (2001) as presented in Figure 10.
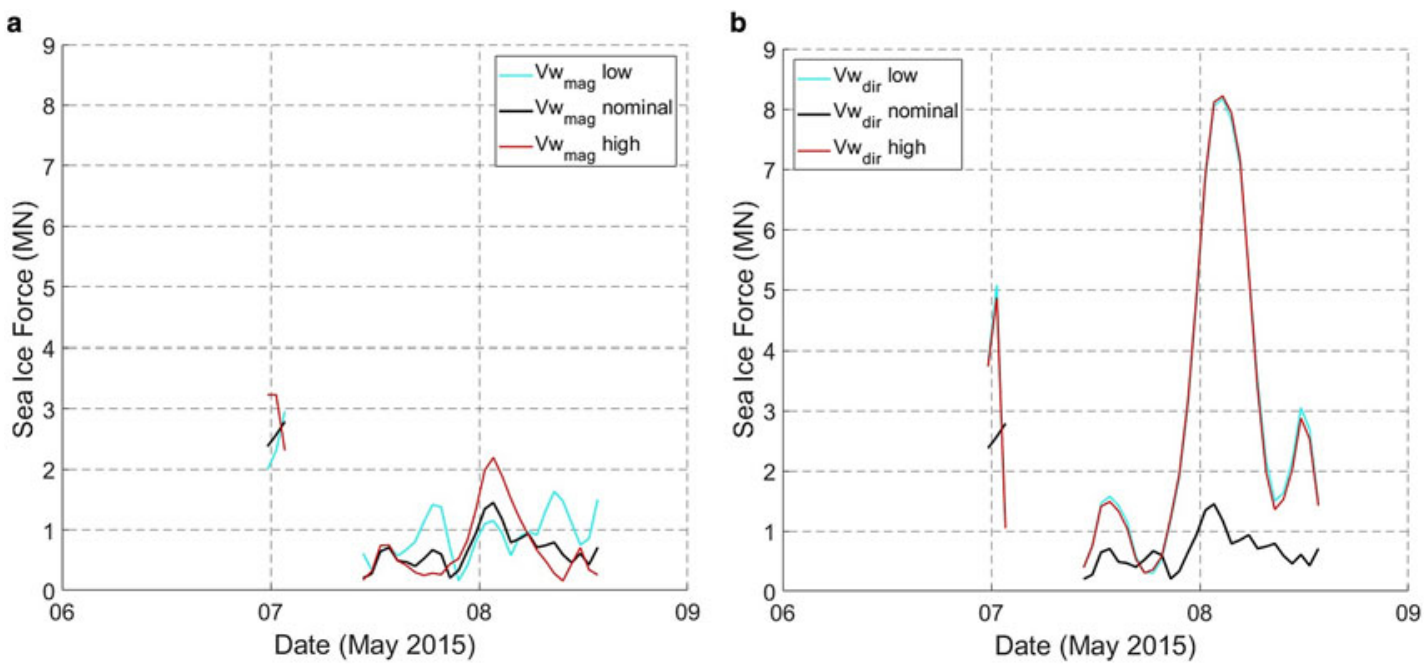

Fig. 15. The residual sea-ice force magnitude on the ice island fragment tracked by beacon 1700 , calculated using a residual approach (Turnbull and others, 2017) with varying ocean currents speed (a) and direction (b). Bold lines (in black) indicate the nominal values used in the study. The residual ice force magnitudes were only presented for the drifting periods when sea ice was present. 
The sensitivity analysis presented here supports the conclusion that the discrepancy between the sea-ice forces from the two models is most likely linked to the error in the extracted ocean currents.

\section{Conclusions}

This study presented an analysis of the relative influences of atmospheric and oceanic forces on the drift of four ice island fragments tracked offshore Newfoundland during spring/summer of 2015. The four fragments were assumed to drift under the influence of the forces due to wind, ocean currents, Coriolis deflection, sea surface tilt and sea ice. The variations in the masses of the fragments over their drift periods were calculated from a combination of satellite imagery data, a surface ablation (TIM) model and a basal ablation model to account for both of the horizontal deterioration and the thickness melt of the ice island fragments over time. Given that the tracking beacons provided accurate positional measurements, through which the drift average velocity and acceleration were calculated, the net force and the Coriolis force on the fragments were relatively well-constrained. The wind and sea surface altimetry data, which were obtained from reanalysis data and satellite measurements, respectively, allowed the forces due to wind and sea surface tilt to be also wellconstrained. The ocean current force, however, was not wellconstrained due to the uncertainly in the CMEMS currents. The force caused by the surrounding sea ice was calculated as the difference between the net force (i.e. the force that would be required to account for the observed drift) and the sum of force due to wind, ocean currents, Coriolis effect and sea surface tilt. This was then compared against the sea-ice force calculated from the model proposed by Lichey and Hellmer (2001). Constraining the forces due to wind, sea surface tilt and Coriolis effect, coupled with the net force on the fragments, allowed the reliability of the sea-ice force model from the residual approach to rest upon fairly accurate estimation of ocean currents over the periods the fragments were analyzed.

The analysis of the forces on the four fragments revealed that, except for the times that sea ice was present at medium-high concentrations and the times that the fragments drifted at higher speeds, the forces due to the ocean currents and sea surface tilt controlled the drift velocity of the fragments, comprising, on average, up to $63 \%$ of the total force experienced by the drifting fragments. The sea-ice forces estimated from the residual approach differed in magnitude from the ones estimated from Lichey and Hellmer's model (2001), mainly due to the uncertainty in CMEMS current velocities, as shown by the presented sensitivity analysis. The wind contributed the least to the total force experienced by the drifting ice island fragments ( $1-5 \%$ on average). The Coriolis force was only significant during the periods that the fragments drifted at high speed. The present study provides an important step forward in characterizing the drift of ice islands within the sea-ice environment offshore Newfoundland under the influence of various driving forces. The results of this study can contribute to the calibration and improvement of the future regional operational ice dynamics models for the east coast of Canada.

Acknowledgements. The field data for this study were collected in collaboration between Equinor and ArcticNet. We thank the captain, crew and helicopter pilot of the CCGS Amundsen as well as Anna Crawford for field assistance. Radarsat-2 data were supplied by the Canadian Ice Service, Environment and Climate Change Canada. Financial support from Hibernia Management and Development Company (HMDC) and the School of Graduate Studies at Memorial University of Newfoundland is gratefully acknowledged.

\section{References}

Banke EG and Smith SD (1984) A Hindcast Study of Iceberg Drift on the Labrador Coast. Dartmouth, Nova Scotia: Bedford Institute of Oceanography.

Bigg GR, Wadley MR, Stevens DP and Johnson JA (1997) Modelling the dynamics and thermodynamics of icebergs. Cold Regions Science and Technology 26(2), 113-135. https://doi.org/10.1016/S0165-232X(97)00012-8.

Braithwaite RJ and Olesen OB (1993) Seasonal variation of ice ablation at the margin of the Greenland ice sheet and its sensitivity to climate change, Qamanârssûp sermia, West Greenland. Journal of Glaciology 39(132), 267-274. https://doi.org/10.3189/S0022143000015938.

Brickman D and Drozdowski A (2012) Development and Validation of a Regional Shelf Model for Maritime Canada based on the NEMO-OPA Circulation Model. Fisheries and Oceans Canada, Maritimes Region.

Crawford AJ (2018) Ice Island Deterioration (PhD dissertation). Department of Geography and Environmental Studies, Carleton University, Ottawa, Canada. https://doi.org/10.22215/etd/2018-13178.

Crawford A and 5 others (2018a) The Canadian ice island drift, deterioration and detection (CI2D3) database. Journal of Glaciology 64(245), 1-5. doi: https://doi.org/10.1017/jog.2018.36.

Crawford AJ, Mueller DR, Humphreys ER, Carrieres T and Tran H (2015) Surface ablation model evaluation on a drifting ice island in the Canadian Arctic. Cold Regions Science and Technology 110, 170-182. https://doi.org/ 10.1016/j.coldregions.2014.11.011.

Crawford AJ, Mueller D and Joyal G (2018b) Surveying drifting icebergs and ice islands: deterioration detection and mass estimation with aerial photogrammetry and laser scanning. Remote Sensing 10(4), 575. https://doi.org/ 10.3390/rs10040575.

Crepon M, Houssais MN and Guily BS (1988) The drift of icebergs under wind action. Journal of Geophysical Research: Oceans 93(C4), 3608-3612. https://doi.org/10.1029/JC093iC04p03608.

Crocker G, Carrieres T and Tran H (2013) Ice island drift and deterioration forecasting in eastern Canada. In Proceedings of the 22nd International Conference on Port and Ocean Engineering Under Arctic Conditions, Espoo, Finland, pp. 9-13.

Eik K (2009) Iceberg drift modelling and validation of applied Metocean hindcast data. Cold Regions Science and Technology 57(2-3), 67-90. https://doi. org/10.1016/j.coldregions.2009.02.009.

El-Tahan MS, EI-Tahan HW and Venkatesh S (1983) Forecast of iceberg ensemble drift. Proceedings 1983 Offshore Technology Conference, pp. 151-158. https://doi.org/10.4043/4460-MS.

El-Tahan M, Venkatesh S and El-Tahan H (1987) Validation and quantitative assessment of the deterioration mechanisms of Arctic icebergs. Journal of Offshore Mechanics and Arctic Engineering 109(1), 102-108. doi: 10.1115/ 1.3256983 .

Enderlin EM and Hamilton GS (2014) Estimates of iceberg submarine melting from high-resolution digital elevation models: application to Sermilik Fjord, East Greenland. Journal of Glaciology 60(224), 1084-1092. https:/ doi.org/10.3189/2014JoG14J085.

Fujino K, Lewis EL and Perkin RG (1974) The freezing point of seawater at pressures up to 100 bars. Journal of Geophysical Research 79(12), 1792-1797. https://doi.org/10.1029/JC079i012p01792.

Halliday EJ, King T, Bobby P, Copland L and Mueller D (2012) Petermann ice island 'A' survey results, offshore Labrador. OTC Arctic Technology Conference, Offshore Technology Conference. https://doi.org/10.4043/23714-MS.

Hibler III WD (1979) A dynamic thermodynamic sea ice model. Journal of Physical Oceanography 9(4), 815-846. https://doi.org/10.1175/1520-0485 (1979)009\%3C0815:ADTSIM\%3E2.0.CO;2.

Hock R (2003) Temperature index melt modeling in mountain areas. Journal of Hydrology 282, 104-115. https://doi.org/10.1016/S0022-1694(03)00257-9.

Hock R (2005) Glacier melt: a review of processes and their modelling. Progress in Physical Geography 29(3), 362-391. https://doi.org/10.1191\% 2F0309133305pp453ra.

Jeffries MO (2002) Glaciers of the arctic islands Ellesmere Island ice shelves and ice islands. US Geological Survey professional paper (1386J).

Job JG (1978) Numerical modelling of iceberg towing for water supplies - a case study. Journal of Glaciology 20(84), 533-542. https://doi.org/10.3189/ S002214300002092X.

Josberger EG (1978) A laboratory and field study of iceberg deterioration. In Iceberg Utilization, pp. 245-264. https://doi.org/10.1016/B978-0-08-0229164.50027-3. 
Keghouche I, Bertino L and Lisæter KA (2009) Parameterization of an iceberg drift model in the Barents Sea. Journal of Atmospheric and Oceanic Technology 26(10), 2216-2227. https://doi.org/10.1175/2009JTECHO678.1.

Kubat I, Sayed M, Savage SB and Carrieres T (2005) An operational model of iceberg drift. International Journal of Offshore and Polar Engineering 15(2), 125-131.

Kubat I, Sayed M, Savage SB, Carrieres T and Crocker G (2007) An operational iceberg deterioration model. Proceedings of the 17th International Offshore Polar Engineering Conference, held 1-6 July in Lisbon, Portugal, pp. 652-657.

Lellouche JM and 10 others (2018) Recent updates to the Copernicus Marine Service global ocean monitoring and forecasting real-time $1 / 12^{\circ}$ highresolution system. Ocean Science 14(5), 1093-1126. https://doi.org/10. 5194/os-14-1093-2018.

Lichey C and Hellmer HH (2001) Modeling giant-iceberg drift under the influence of sea ice in the Weddell Sea, Antarctica. Journal of Glaciology 47(158), 452-460. https://doi.org/10.3189/172756501781832133.

Løset S (1993) Numerical modelling of the temperature distribution in tabular icebergs. Cold Regions Science and Technology 21(2), 103-115.

Mountain DG (1980) On predicting iceberg drift. Cold Regions Science and Technology 1, 273-282. https://doi.org/10.1016/0165-232X(80)90055-5.

Mueller D, Crawford A, Copland L and Van Wychen W (2013) Ice island and iceberg fluxes from Canadian High Arctic sources. Report prepared for the Northern Transportation Assessment Initiative, Innovation Policy Branch, Transport Canada, Ottawa, Ontario.

Murphy DL and Anderson LT (1986) An evaluation of the international ice patrol drift model. Proceedings of the Canadian East Coast Workshop on Sea Ice, Canadian Technical Report of Hydrological and Ocean Sciences, 73, pp. 387-409.

Murphy DL and Carrieres T (2010) CIS-IIP iceberg model inter-comparison. Report prepared for the North American Ice Service, p. 27.

Peterson IK, Prinsenberg SJ, Pittman M and Desjardins L (2009) The drift of an exceptionally-large ice island from the Petermann Glacier in 2008. In Proceedings of the International Conference on Port and Ocean Engineering Under Arctic Conditions (No. POAC09-130).
Rackow T and 5 others (2017) A simulation of small to giant Antarctic iceberg evolution: differential impact on climatology estimates. Journal of Geophysical Research: Oceans 122(4), 3170-3190. https://doi.org/10.1002/ 2016JC012513.

Savage SB (2001) Aspects of iceberg deterioration and drift. In Balmforth NJ and Provenzale A (eds), Geomorphological Fluid Mechanics, Lecture Notes in Physics Series, vol. 582. Berlin: Springer-Verlag, 279-318. https://doi. org/10.1007/3-540-45670-8_12.

Scambos T, Sergienko O, Sargent A, MacAyeal D and Fastook J (2005) ICESat profiles of tabular iceberg margins and iceberg breakup at low latitudes. Geophysical Research Letters 32(23). https://doi.org/10.1029/ 2005GL023802.

Smith SD (1993) Hindcasting iceberg drift using current profiles and winds. Cold Regions Science and Technology 22(1), 33-45. https://doi.org/10. 1016/0165-232X(93)90044-9.

Smith SD and Banke EG (1983) The influence of winds, currents and towing forces on the drift of icebergs. Cold Regions Science and Technology 6(3), 241-255. https://doi.org/10.1016/0165-232X(83)90045-9.

Smith S and Donaldson N (1987). Innovations in dynamic modelling of iceberg drift. In OCEANS'87 IEEE, 5-10. https://doi.org/10.1109/OCEANS. 1987.1160880

Turnbull ID (2010) Drift of large tabular icebergs in response to atmospheric surface pressure gradients, an observational study. Antarctic Science 22(2), 199-208. https://doi.org/10.1017/S0954102010000027.

Turnbull ID, Torbati RZ and Taylor RS (2017) Relative influences of the meteorological and oceanic forcings on the drifting ice pack and estimation of internal ice stress gradients in the Labrador Sea. Journal of Geophysical Research: Oceans 122(7), 5970-5997. https://doi.org/10.1002/ 2017JC012805.

White FM, Spaulding ML and Gominho L (1980) Theoretical estimates of the various mechanisms involved in iceberg deterioration in the open ocean environment. U.S. Coast Guard Research and Development Center Report, p. 126. 